\title{
ضوابط تدبير الاختلاف مع الآخر في أصول التراث الإسلامي
}

\section{*مماد رفيع}

مقدمة:

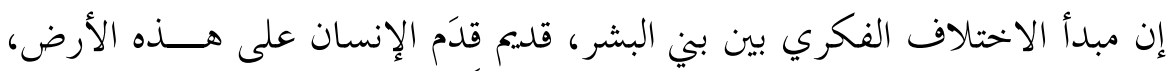

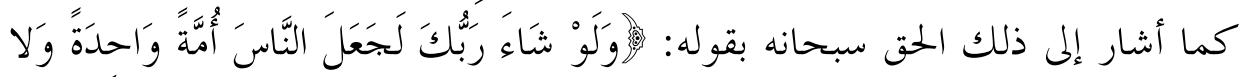

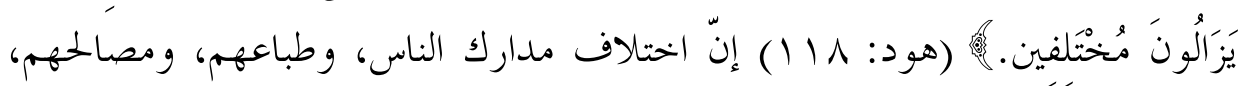

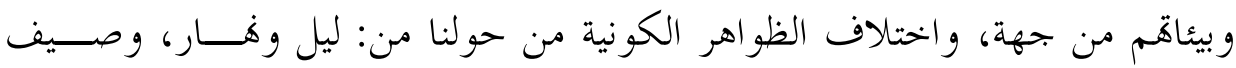

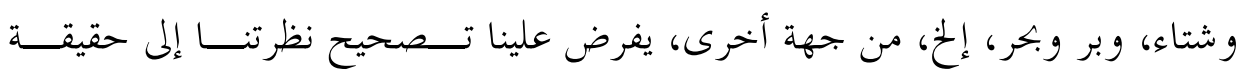

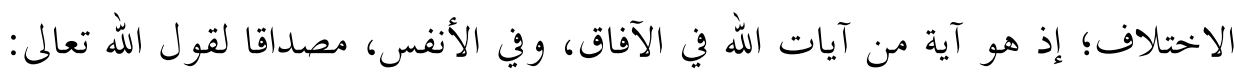

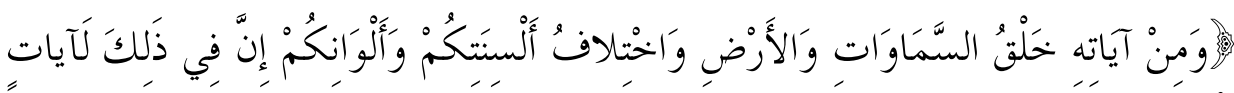

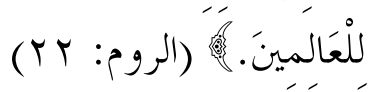

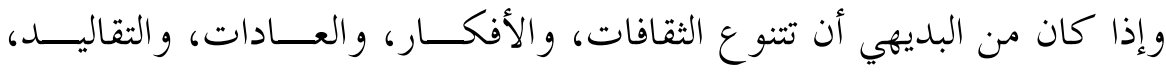

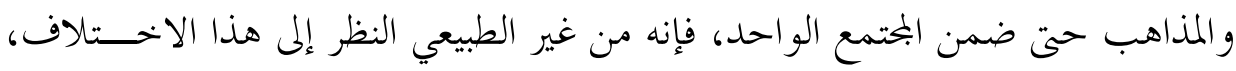

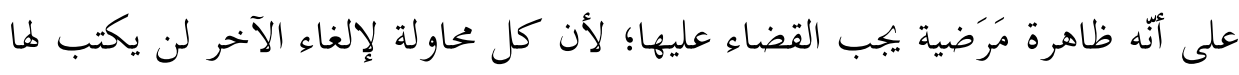
النجاح، كما حدث للتجربة الشيوعية، التي حاولت بكل ما أوتيت من و سائل القمع، إلغاء كل ما هو غير شيوعي، فكانت النتيجة اهيار كل ما هو شيوعي، وبقاء الآخــــئ

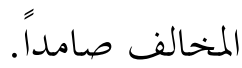

ومن بحليات الرحمة في آية الاختلاف، ما أثبتته الدراسات (السيكو اجتماعية) من

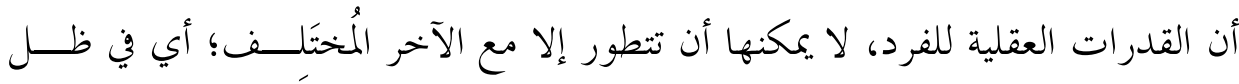

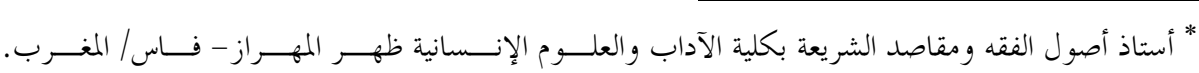
agamroule@yahoo.fr 
التدافع المعرفي، والجدال العلمي، بوصفه البحال الأفضل للتطور الذهني والمعرفي، وتتعزز

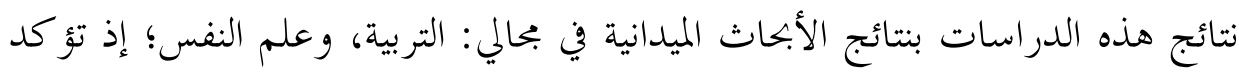

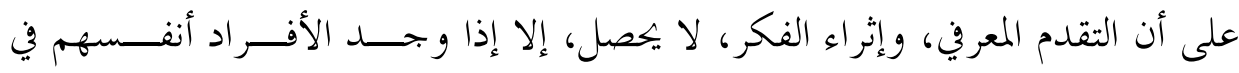

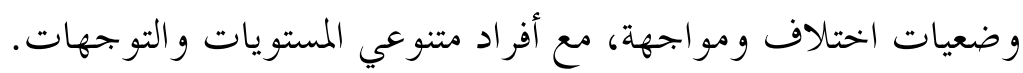

والتدافع المعرفي المفضي إلى إثراء الفكر، يتوقف على وجود اختلافــات في في آراء

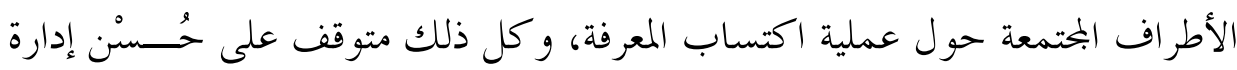
هذا الاختلاف، وتدبيره في الاتجاه الصحيح المنتج.

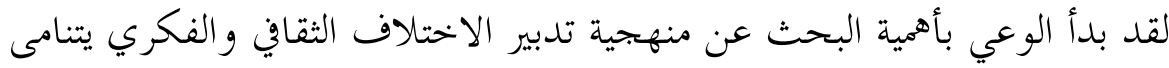

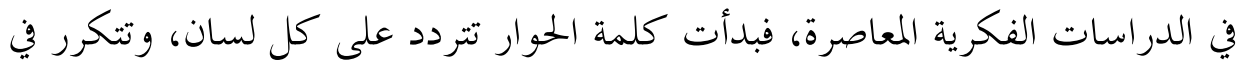

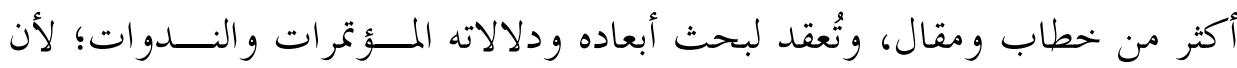

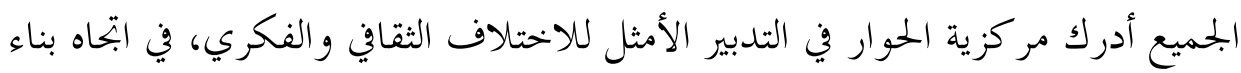

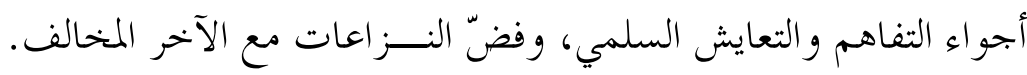

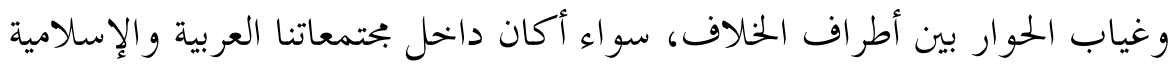

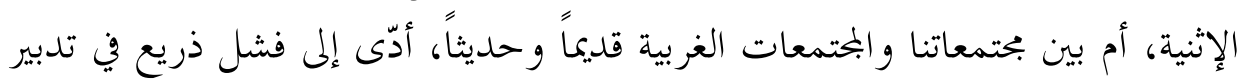

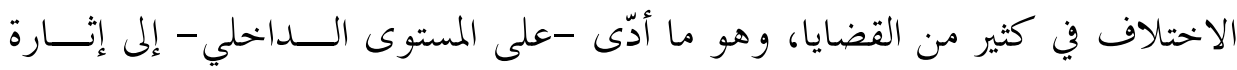

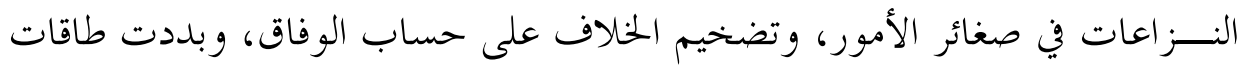

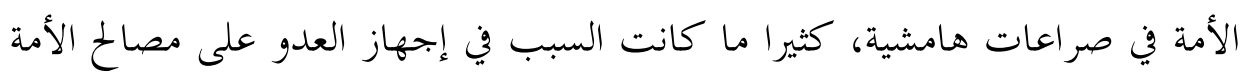

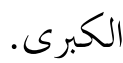

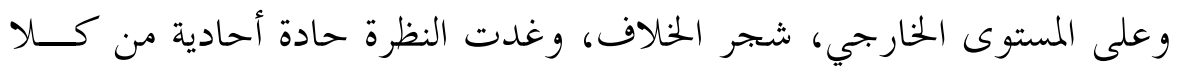

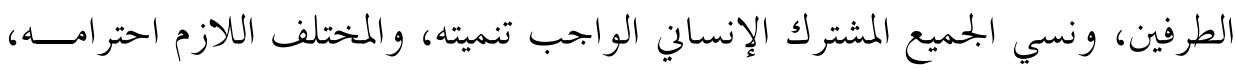

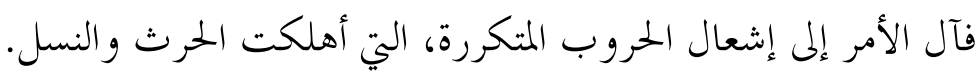
ومن جانبنا، فإن مسؤوليتنا فيما نعيشه من أزمة في العلاقة مع الآخر الوطني، أو الو الوني

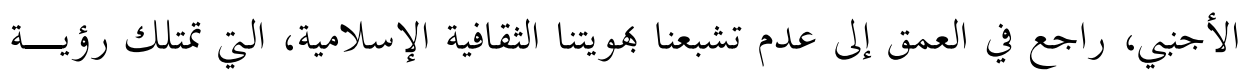

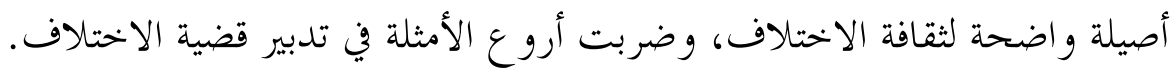


فالقر آن الكريم قدّم لنا منهجاً متكاملاً للحوار في عرض مضامين رســالته، و لم

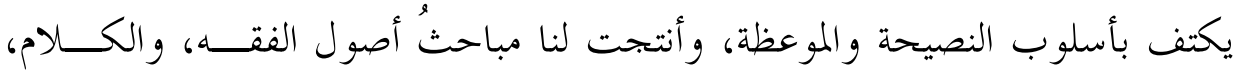

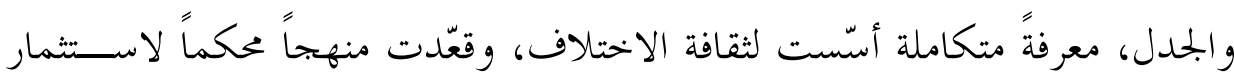
الاختلاف في إنتاج المعرفة وتصحيحها.

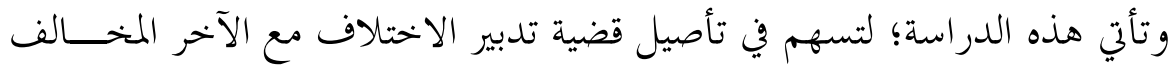

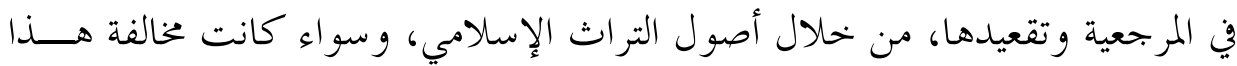

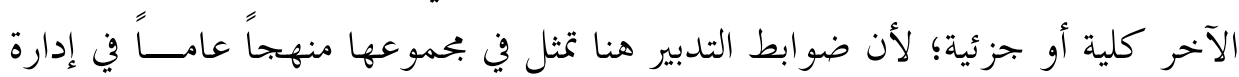
حالات الاختلاف.

\section{أولاً: الأسس المرجعية لتدبير الاختلاف مع الآخر في التراث الإسلامي}

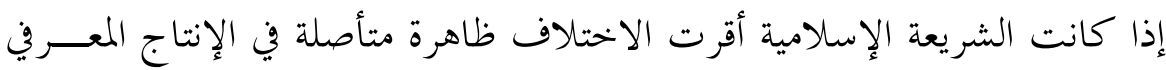

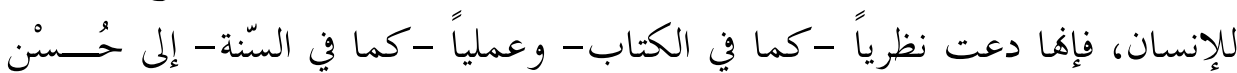

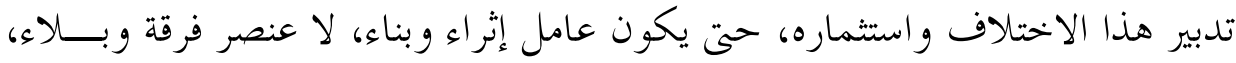

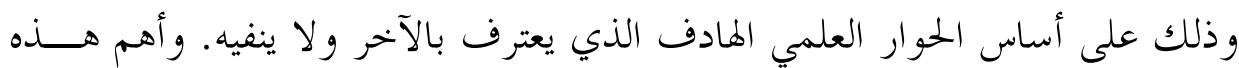
الأسس:

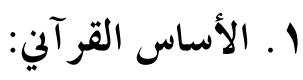

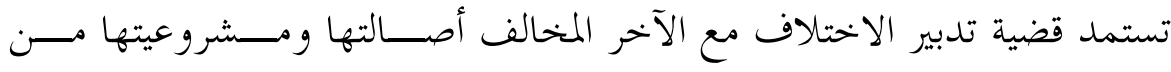

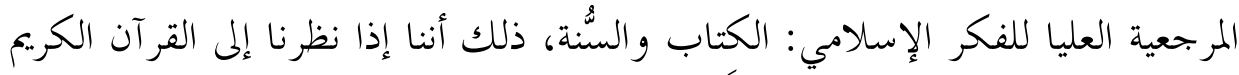

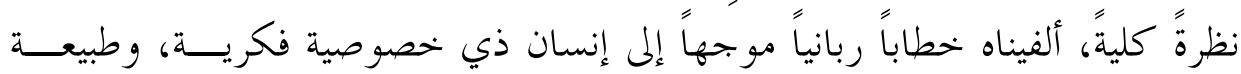

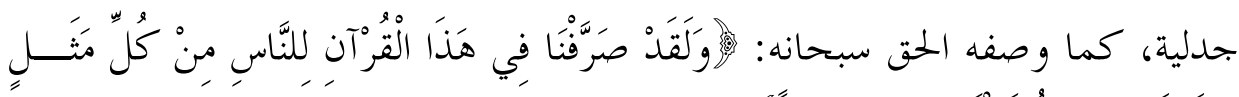

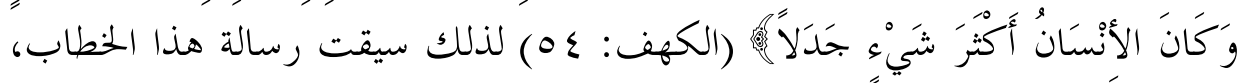

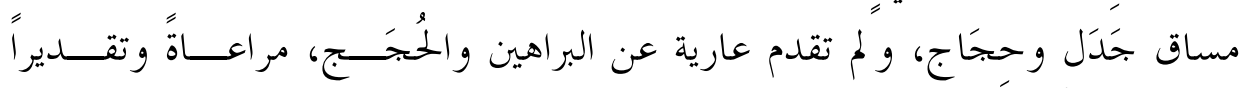

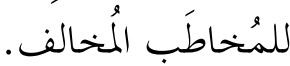




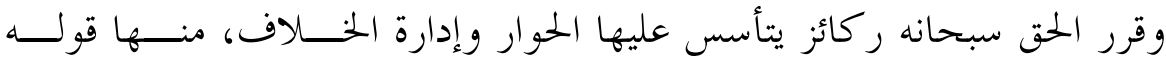

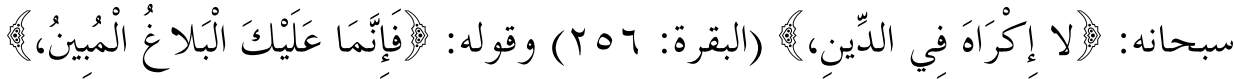

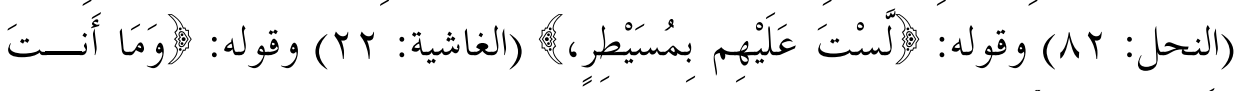

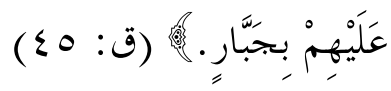

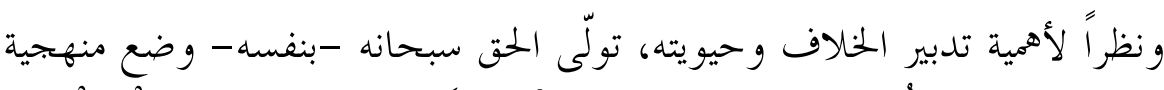

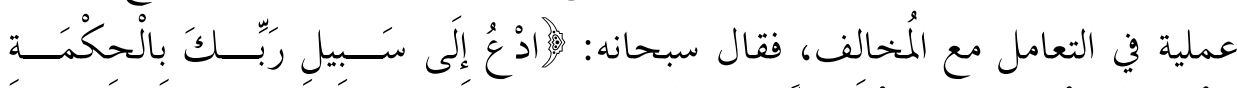

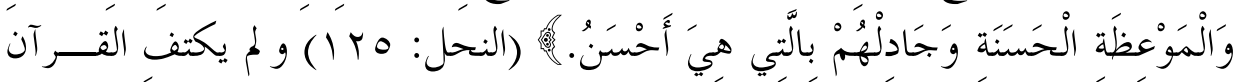

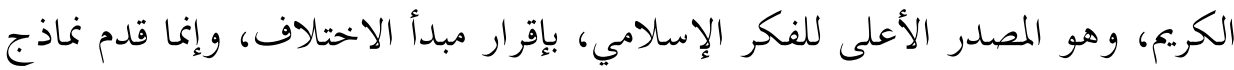

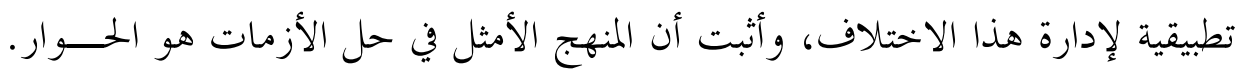

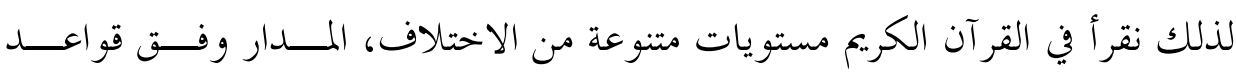

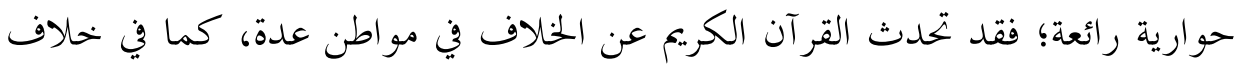

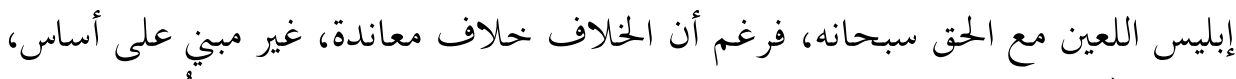

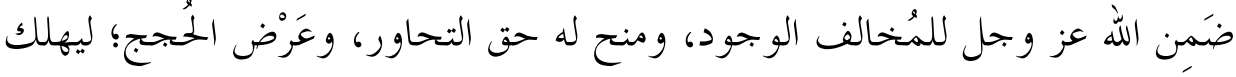

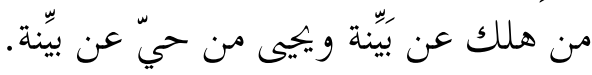

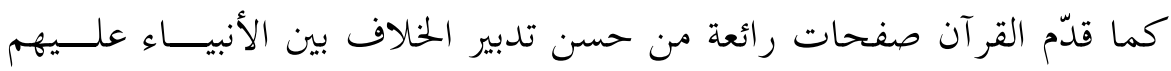

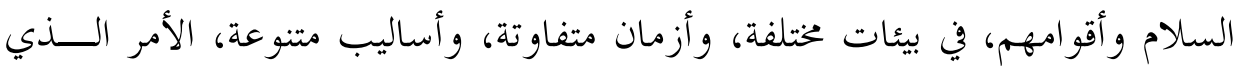

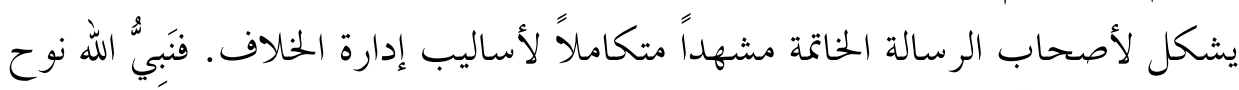

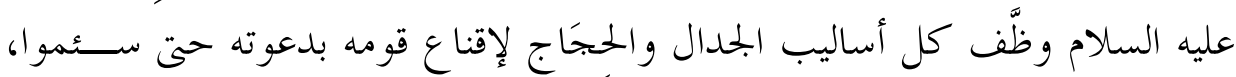

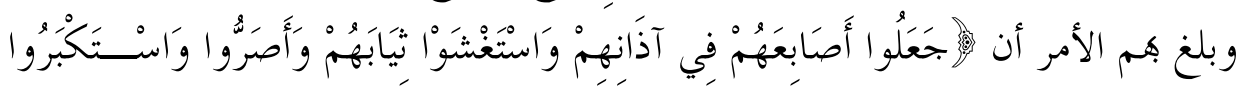

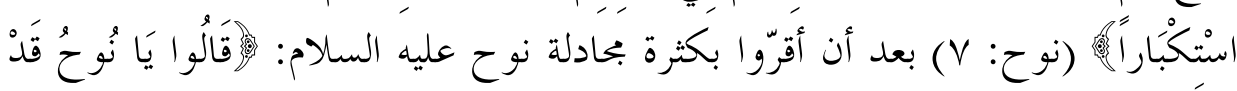

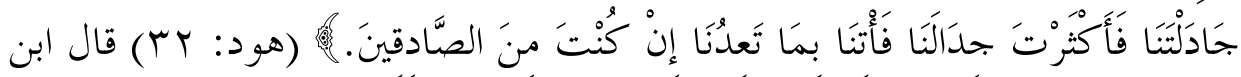

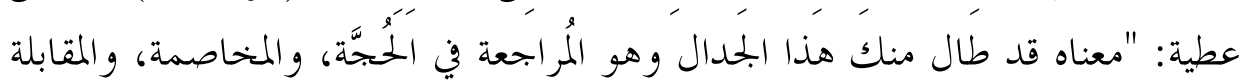

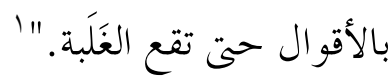
1 ابن عطية الأندلسي، عبد الحق بن غالب. الخرر الوجيز في تفسير الكتاب العزيز، تحقيق الخلس العلمي بككناس،

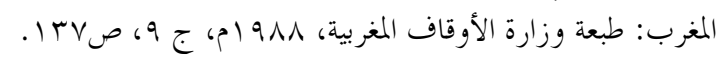




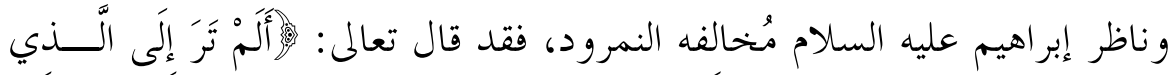

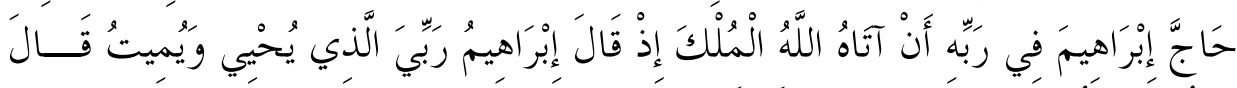

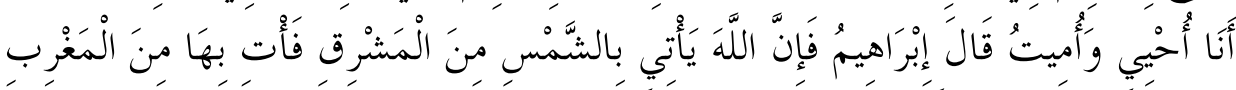

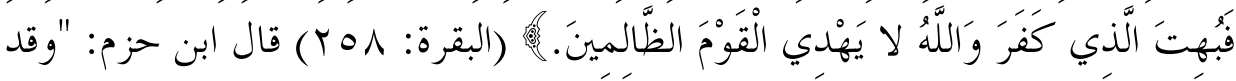

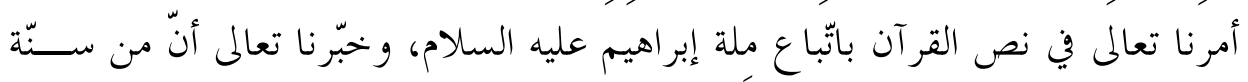

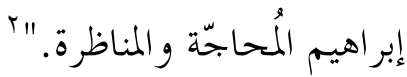

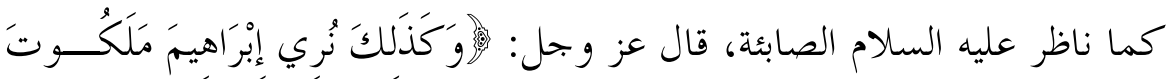

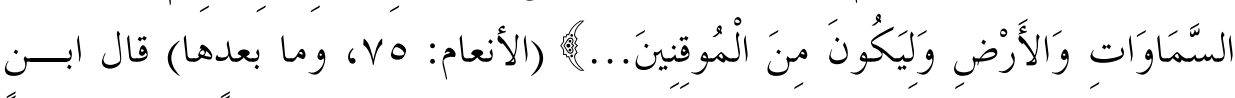

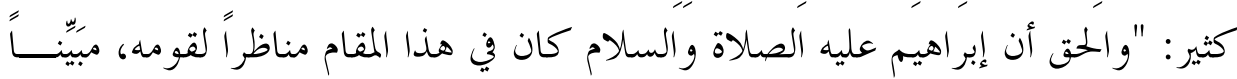

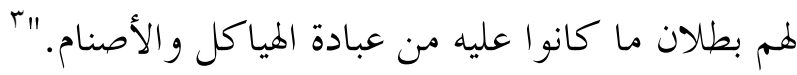

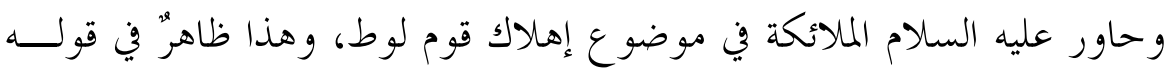

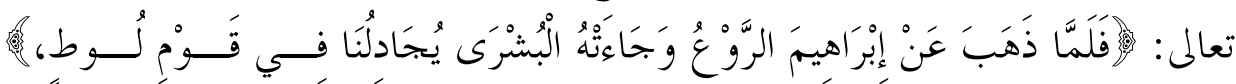

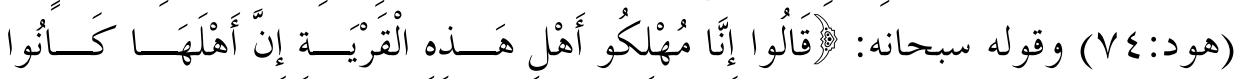

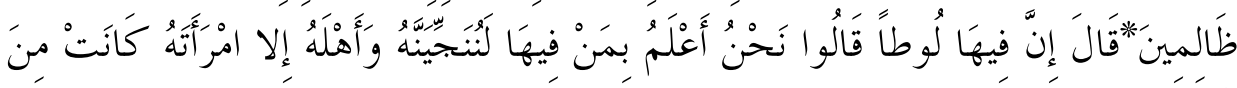

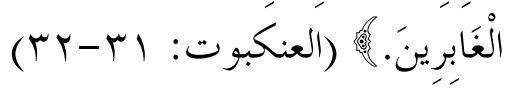

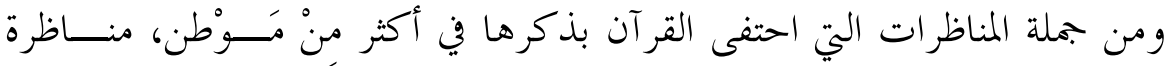

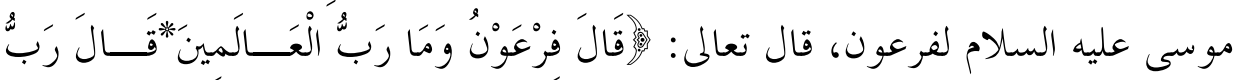

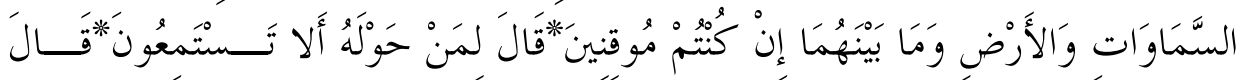

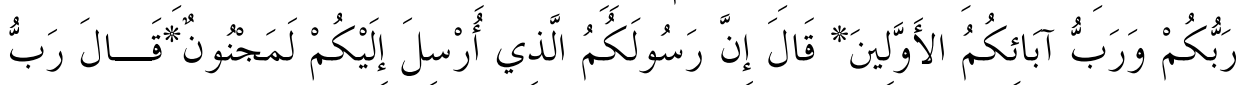

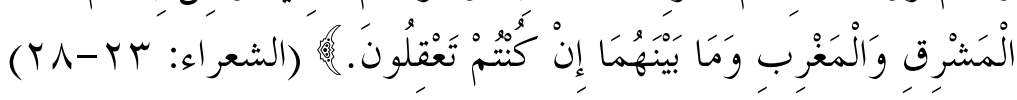

22 ابن حزم الأندلسي، أبو محد علي بن أممد. الإحكام في أصول الأحكام، بيروت: دار الكتب العلميسة، د.ت،

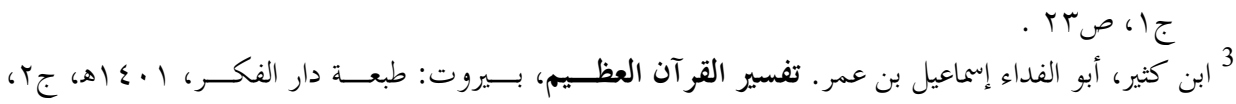




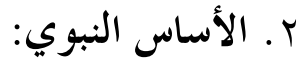

مرحلة النبوة المبار كة مرحلة تأسيس الثقافة الإسلامية، وإرساء دعائمها وأصولها،

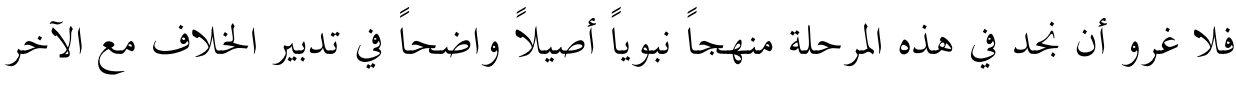

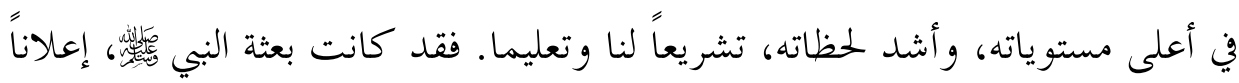

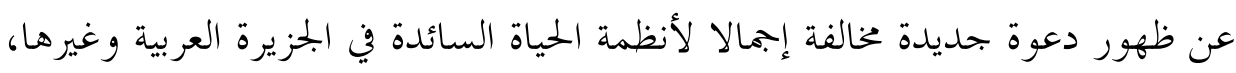

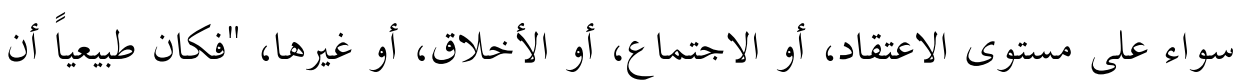

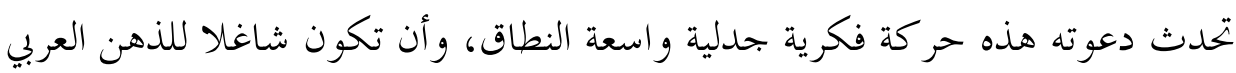

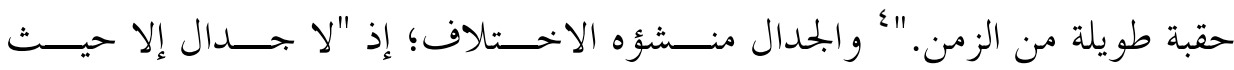

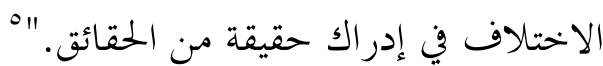

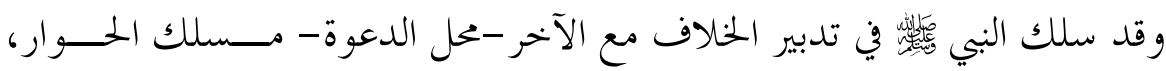

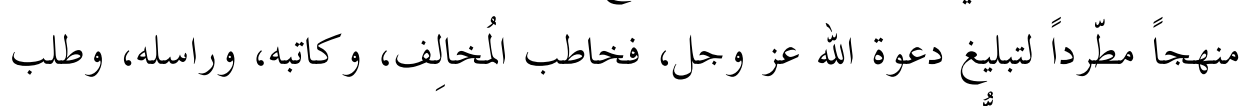

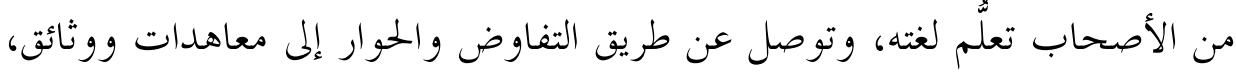

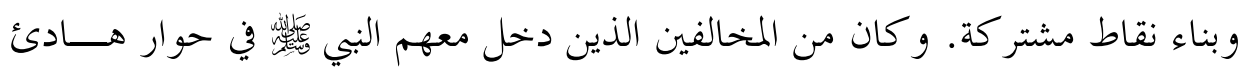
متئد الأصناف التالية:

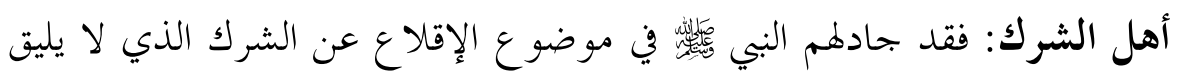

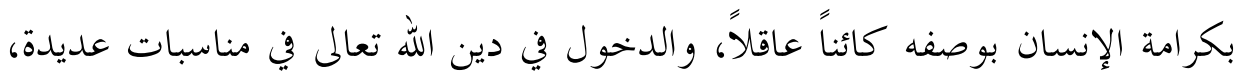

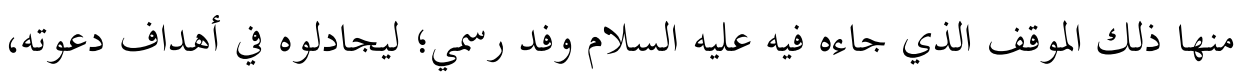

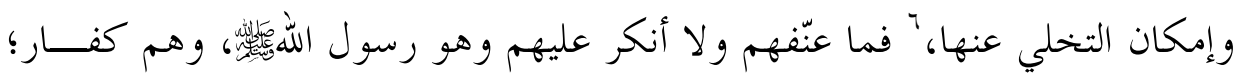

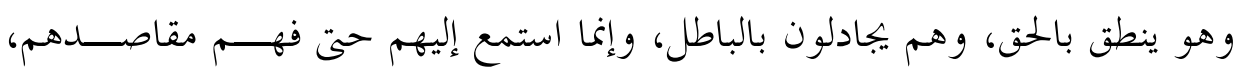

5 أبو زهرة، حمد. تاريخ الجدل، القاهرة: دار الفكر العربي، ــ19 (م) صاءع.

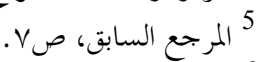
6 انظر تفاصيل تلك المناظرة في:

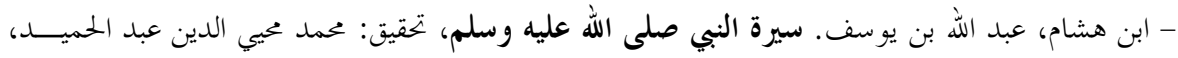

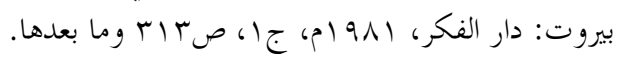




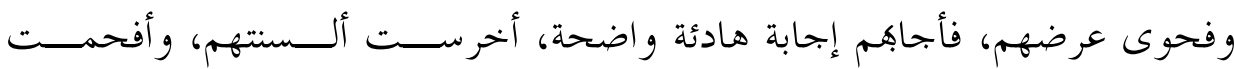
أحلامهم، وهم القوم الخصمون، لذلك قرروا مقاطعة الحوار والإعر اض عن الاستماع،

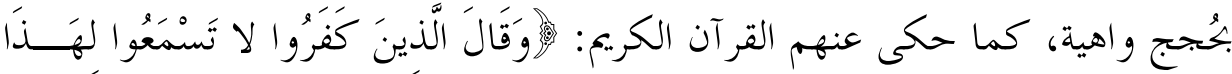

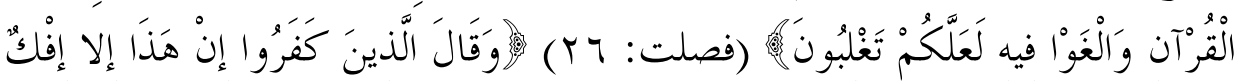

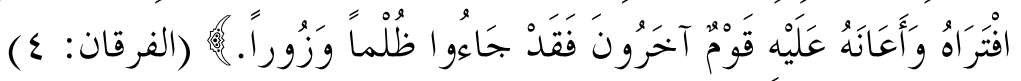

و في القرآن ردو د كثيرة على اعتراضات هؤلاء المشركين ومطالبهم التي لا حدود

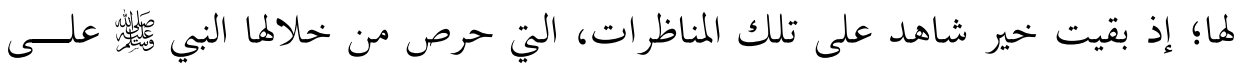

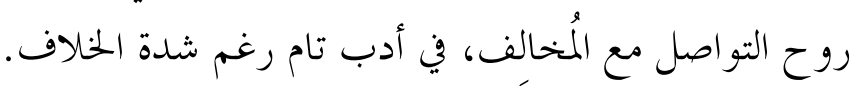

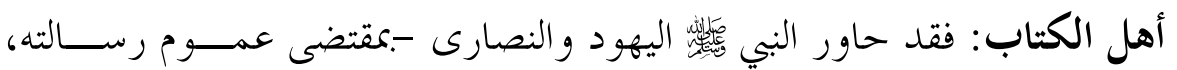

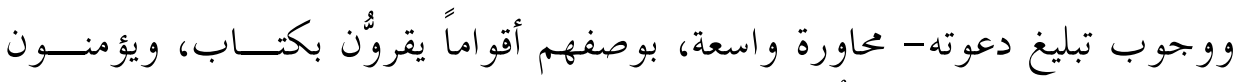

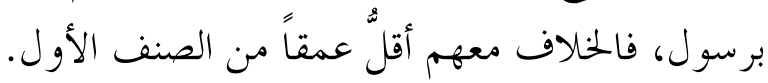

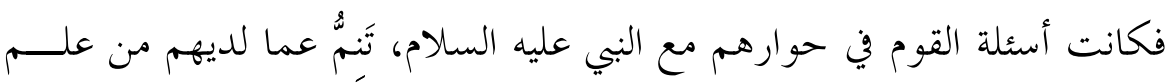

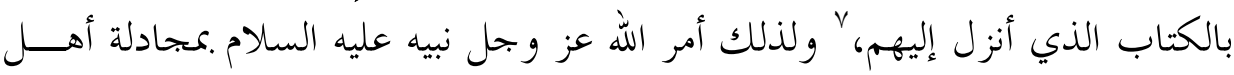

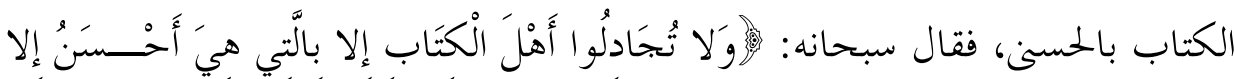

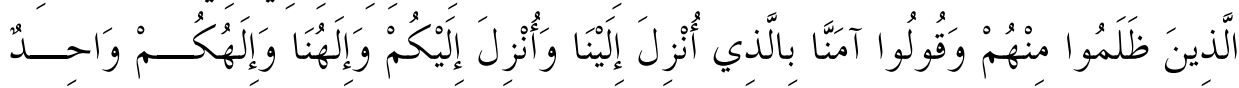

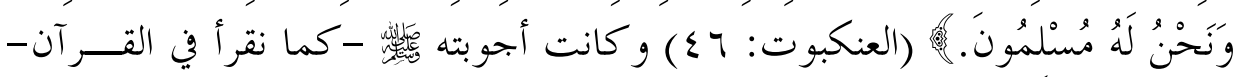

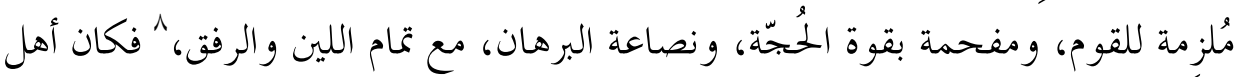

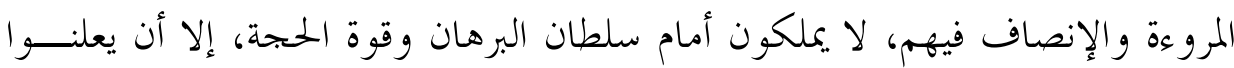
إيماهم كالنجاشي مثلاً، أو يكتموه إلى حين كبعض نصارى بنحران بلان بالمدينة، و وبقي أهل الحقد والعناد في غيهم يعمهون كما هو حال أغلب اليهود.

$$
\begin{aligned}
& \text { انظر نماذج من أسئلتهم في: }
\end{aligned}
$$

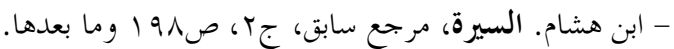

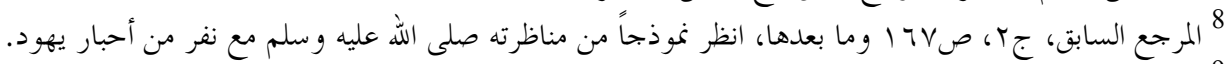

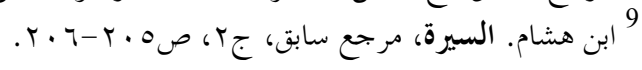


إن منهج الحوار الذي أدار به البي صلى الله عليه و سلم الاختلاف تبليغاً للدعوة،

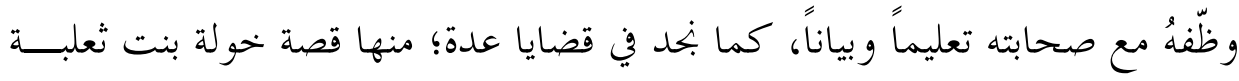

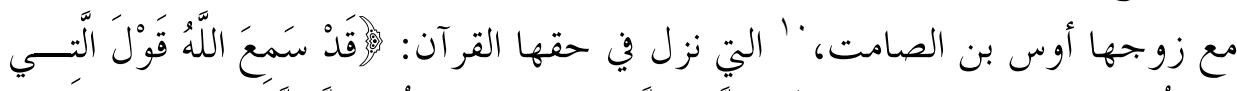

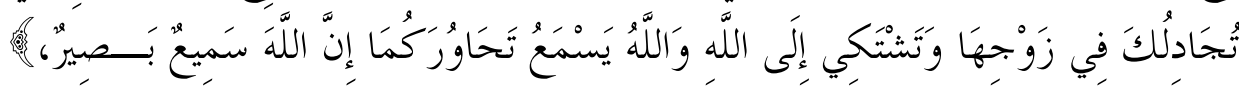

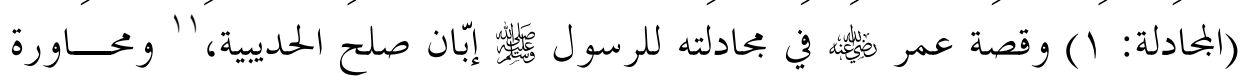
سعد بن معاذ و سعد بن عبادة رضي الله عنهما، في مصالحة الأحزاب بثلث ثمار المدينة

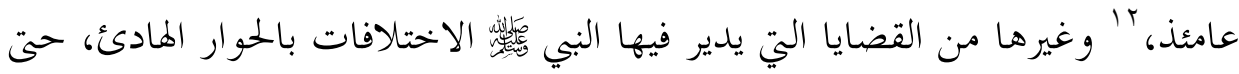

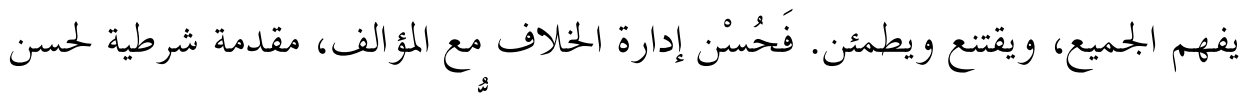

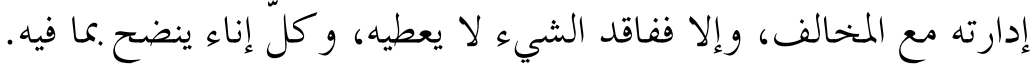

غير أن الناظر في نصوص الشريعة كتاباً وسنّة، في موضوع الاختلاف، يلفيها تارة

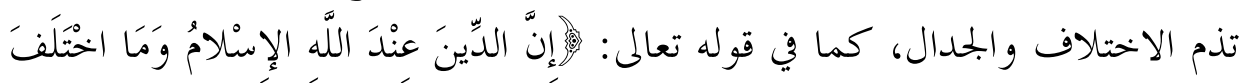

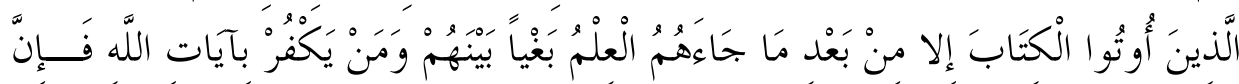

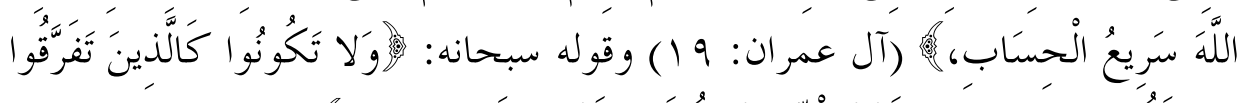

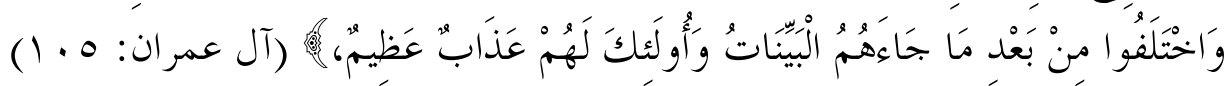

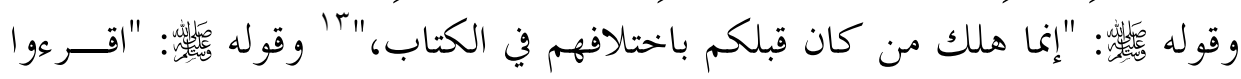

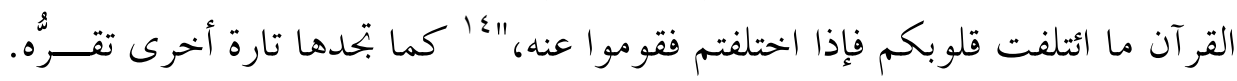

$$
10
$$

- القرطبي، أبو عبد الله عمدد بن أحمد. الجحامع لأحكام القر آن، ط با، بيروت: دار إحياء التـــراث العــربي،

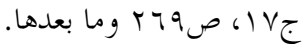

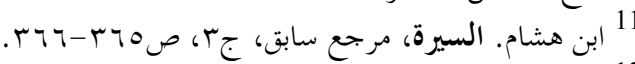

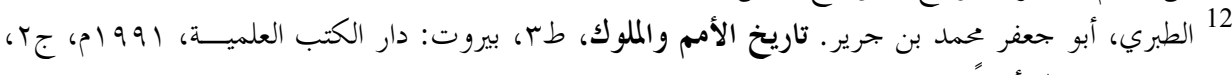

$$
\text { صع } 9.9
$$

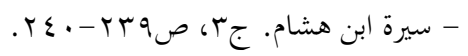

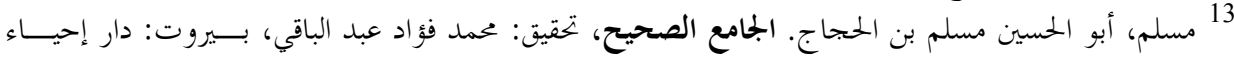

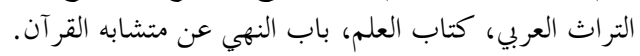

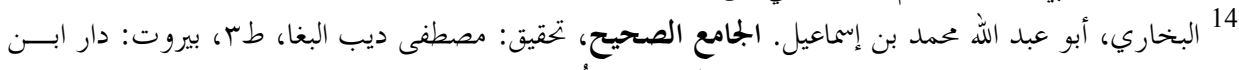

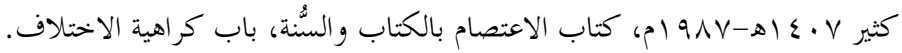


ولكن بعد تأمل مورد الذَّم والإقرار، والرجوع إلى سياق النصوص المتعارضة، يظهر لنا

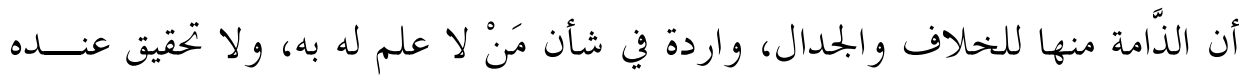

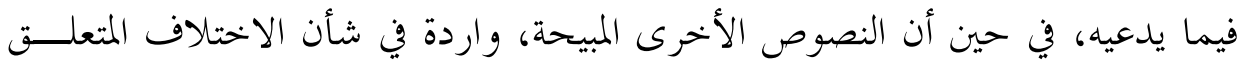

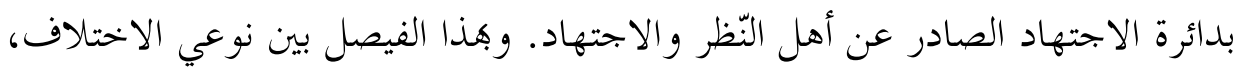

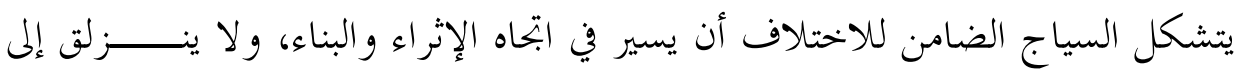

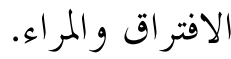

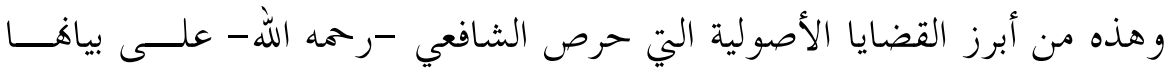

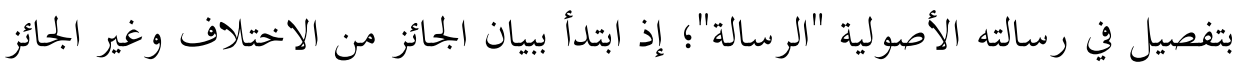

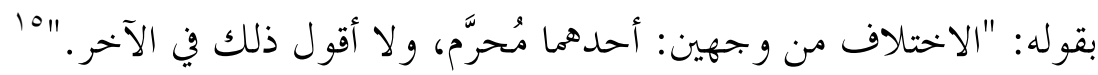

ولقد ظل الاختلاف في الفكر الإسلامي -على المــستوى الـــداخلي - مرتبطــاً

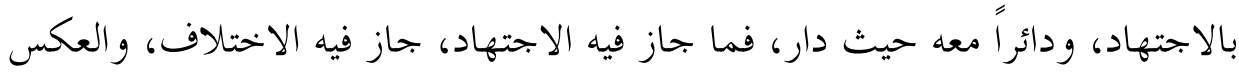
صحيح. ومعلوم أن معظم المعارف التشريعية التي راكمها الفكر الأصولي عبر مسيرته

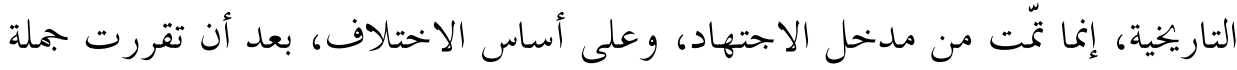

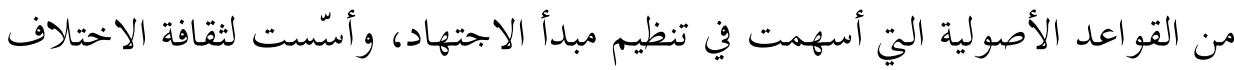
في فضاء البحث التشريعي، نذكر منها: لا إنكار في القضايا الاجتهادية، وأن اجتهاد البحتهد غير ملزم، وأن المختهد لا يجوز له أن يقلد غيره، وأن البختهد مأجور. 17 وإذا كان مدار الاختلاف في الاجتهاد عند جمهور الأصوليين -علــى مـستوى

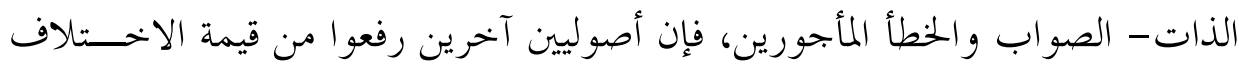

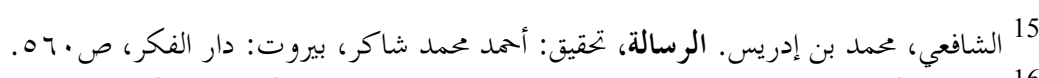

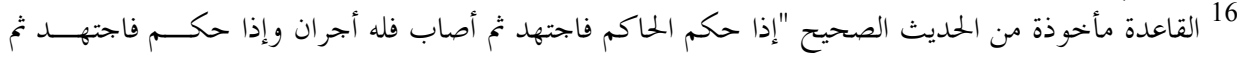

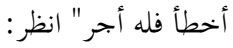
- البخاري. الجلمع الصحيح، مرجع سابق، في كتاب الاعتصام بالكتاب والسُنة، باب أجر الحاكم. 


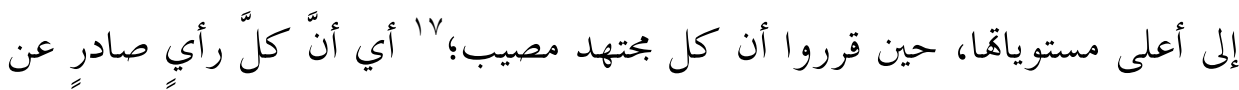

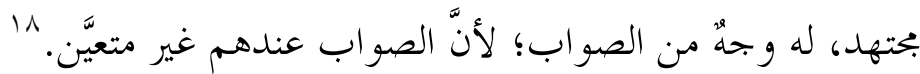

واستلهاماً لروح هذه الرؤية الناضجة لقضية الاختلاف، يعلن الــشافعي قولتــهـ

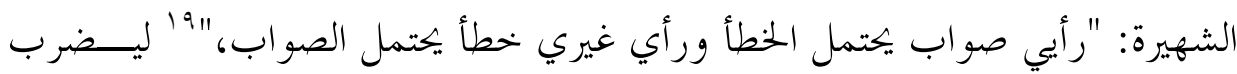

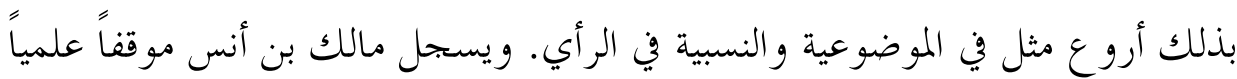

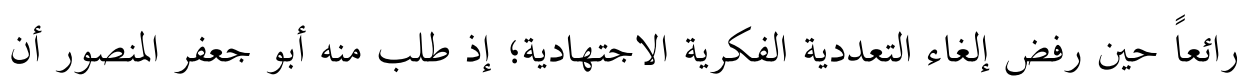

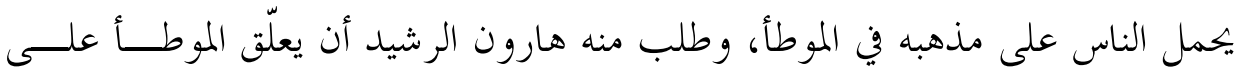

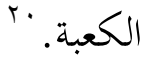

وعلى هذا الأساس ظهرت المدارس الاجتهادية، وتعددت المـــذاهب الفقهيــة،

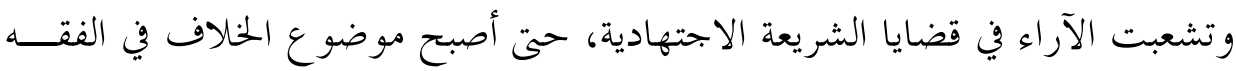

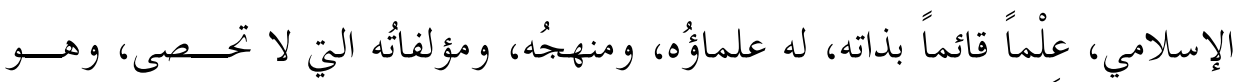
الموسوم بـــالخلاف العالي،" أو"الفقه المقارن،" الذي تحول إلى مادة دراسية في المنهاج التعليمي بلمتمعاتنا الإسلامية، وما يزال.

$$
17
$$

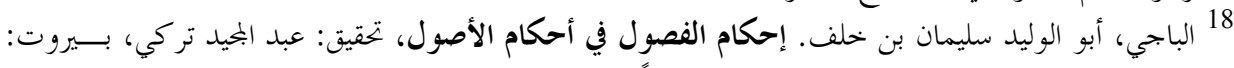

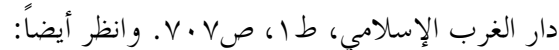

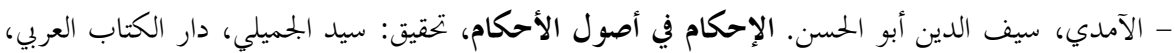

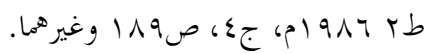

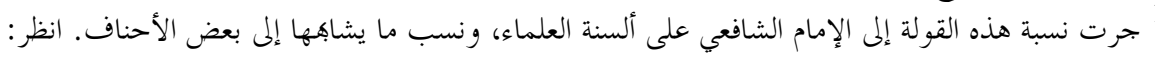
19

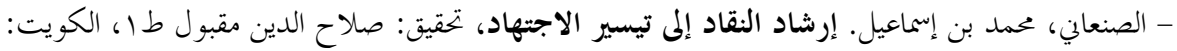

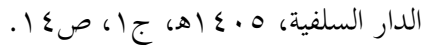

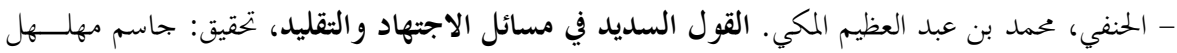

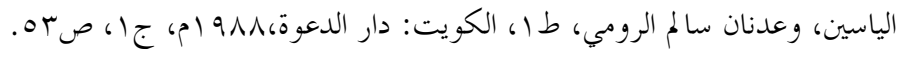

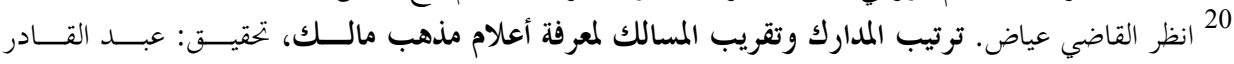

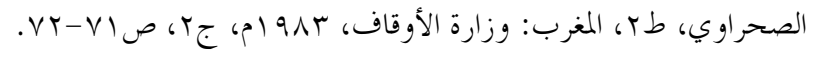




\section{ثانياً: ضوابط تدبير الاختلاف في النظر الأصولي}

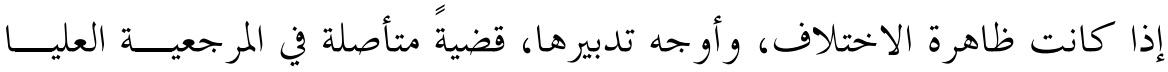

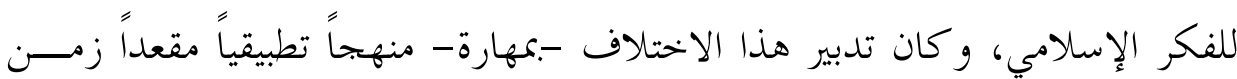

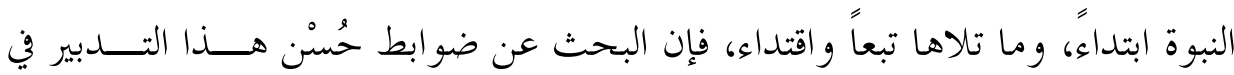

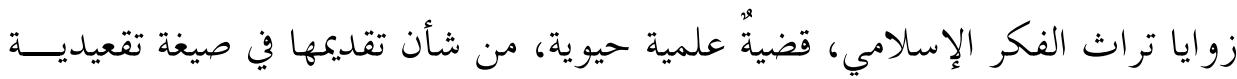

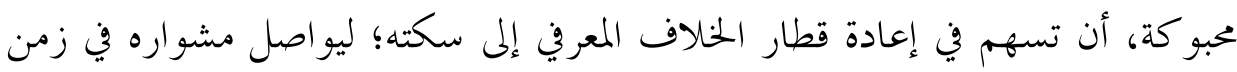

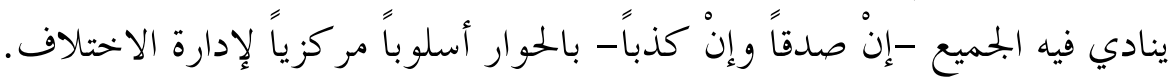
ولقد وجدت الدراسة في تراث الفكر الإسلامي الضوابطَ المعتمــــة في تــــبير

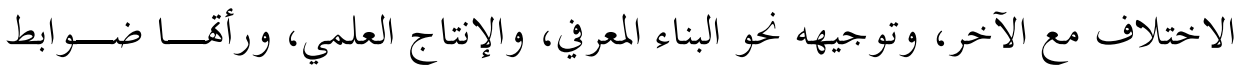

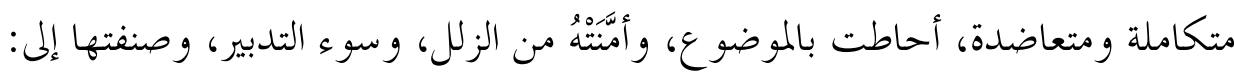
ضو ابط كلية وأخرى تفصيلية:

\section{ا ـ الضوابط الكلية:}

و نقصد هذه الضوابط، جملةَ القضايا التي تشكل في بحموعها السياج العام، الذي

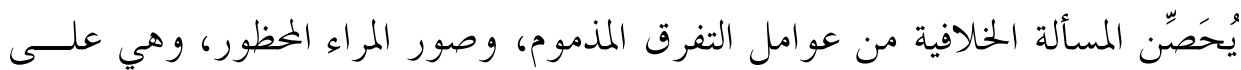
صنفين: الصنف الأول هو ضوابط التأسيس، و الصنف الثاني ضو ابط تأمين الحوار بين المتخالفين.

ونقصد بضو ابط التأسيس الضوابط التي تمتفي ببناء أسـسس الاخهـتلاف المعتــبر

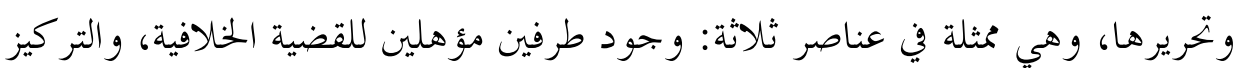

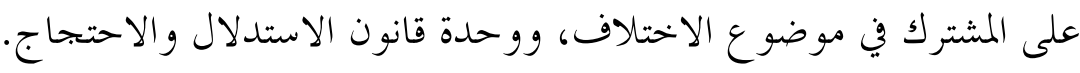

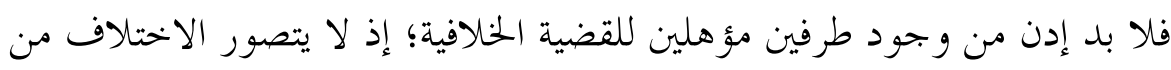

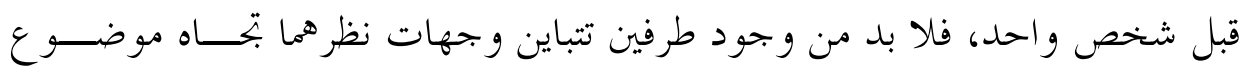

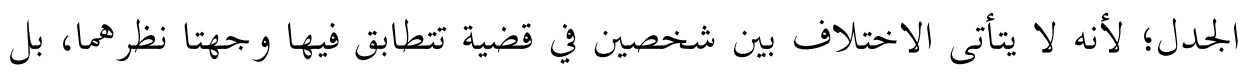


لا بد أن تكون نظرة كل واحد في بداية الأمر تخالف نظرة صاحبه، وقد يفضي الحوار

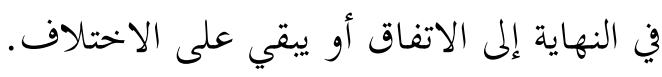

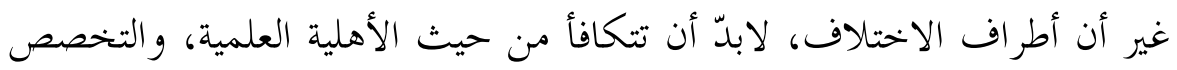

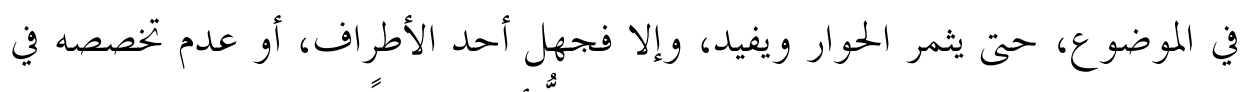

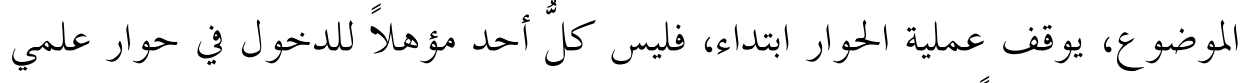

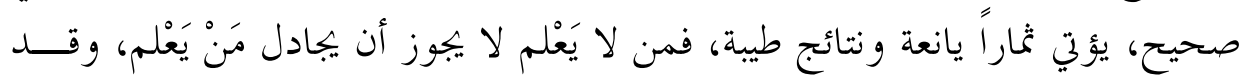

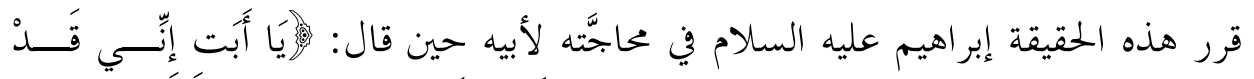

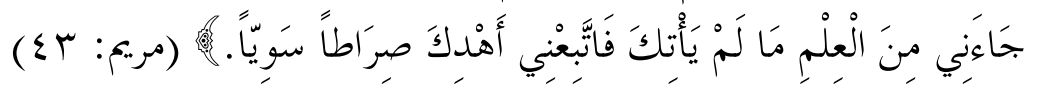

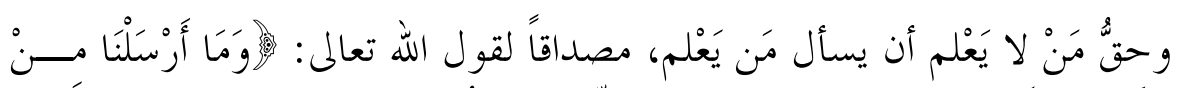

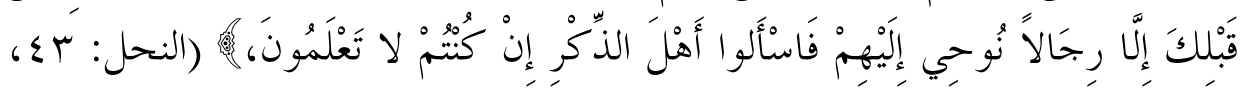

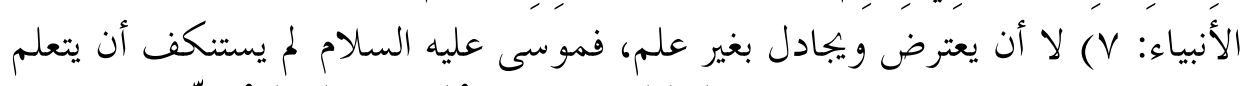

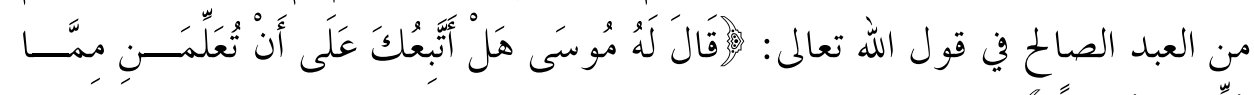

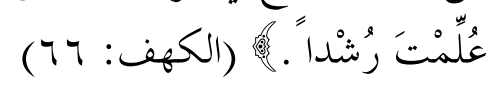

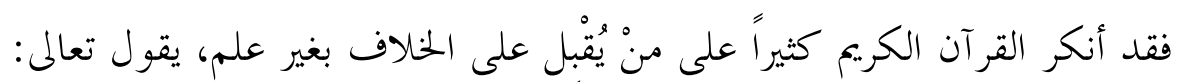

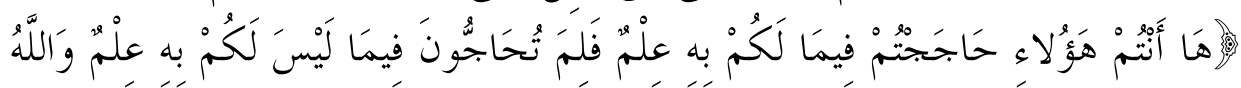

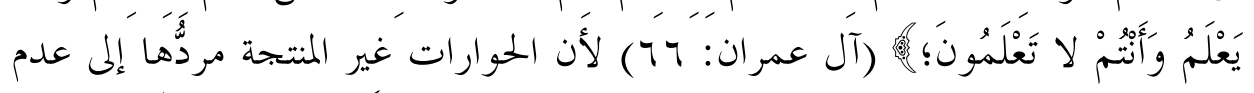

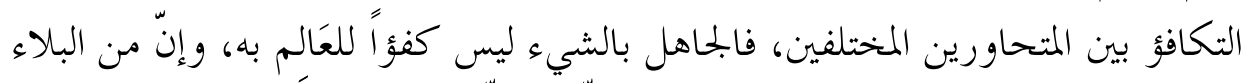

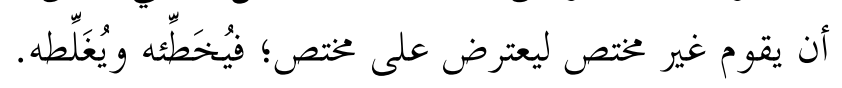

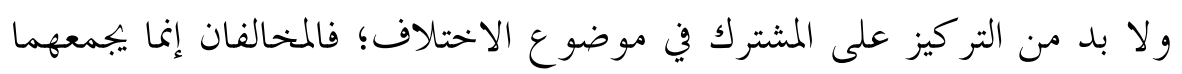

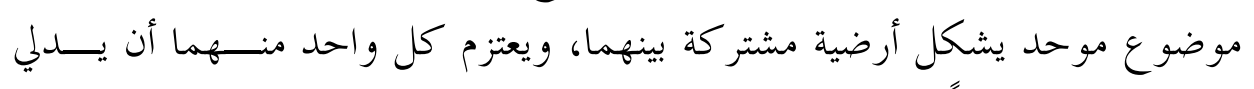

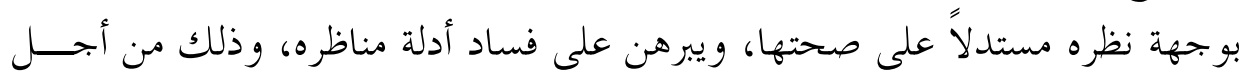

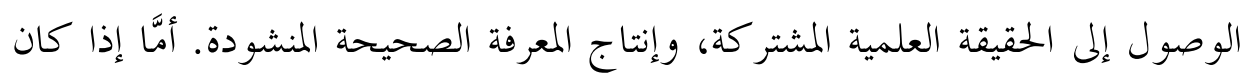

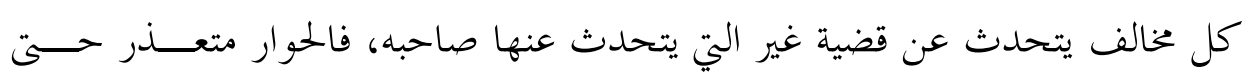

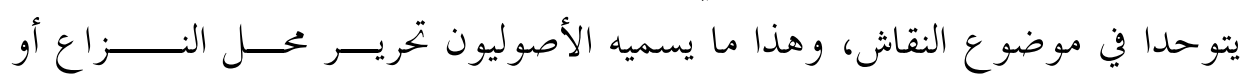




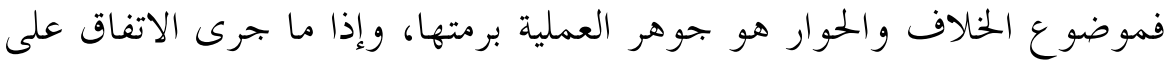

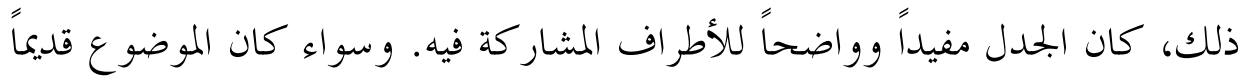

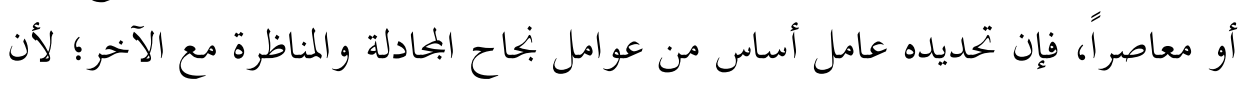

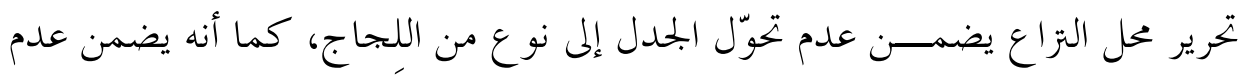

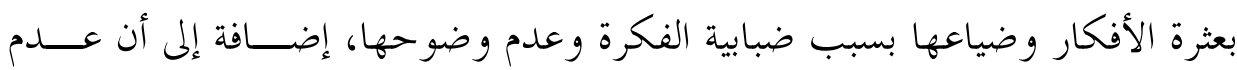

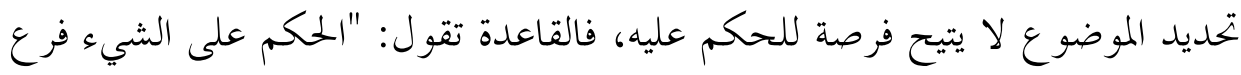

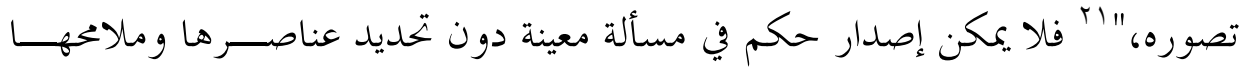
الأساسية.

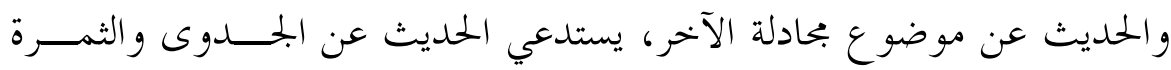

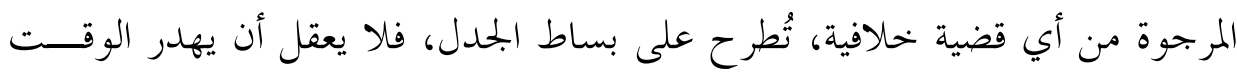

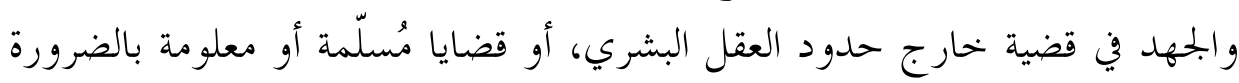

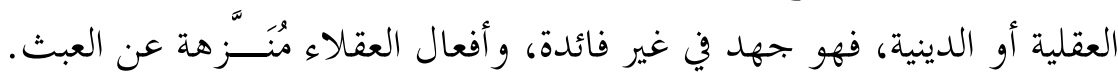

فقد دعا القر آن الكريم أهل الكتاب إلى التركيز على النقاط المشتركة، التي تشكل

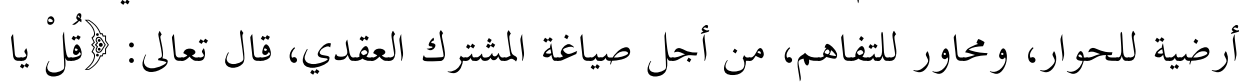

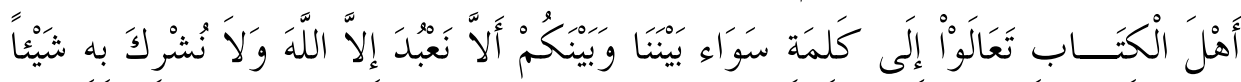

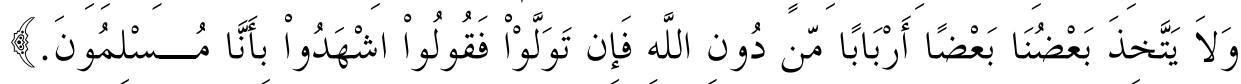

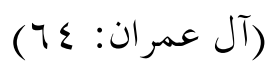

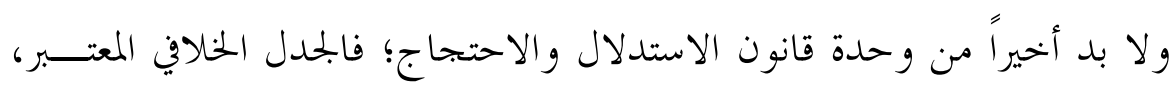

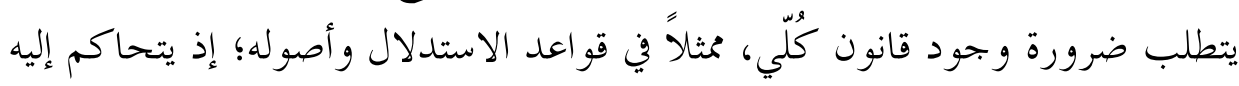

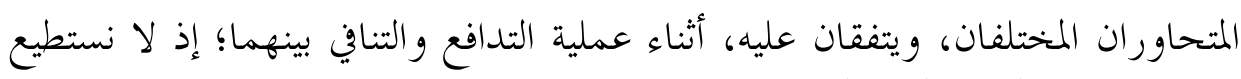

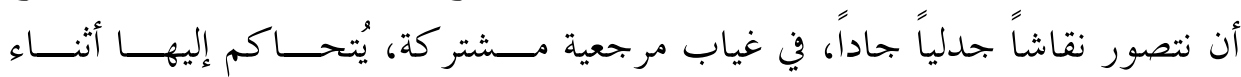
الاستدلال، نفياً أو إثباتاً.

21 السبكيان، علي وولده تاج الدين. الإهاج في شرح المنهاج على منهاج الوصول إلى علم الأصول للقاضـي

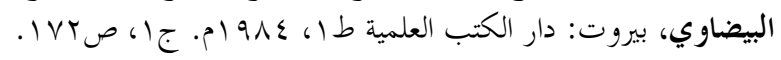


وقد أنكر القرآن الكريم على من بتحاوز البديهيات والقضايا الفطرية المسلمة؛

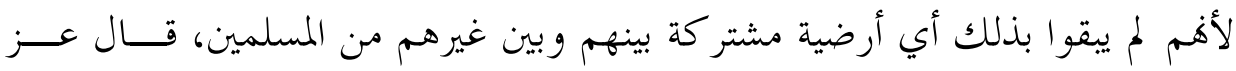

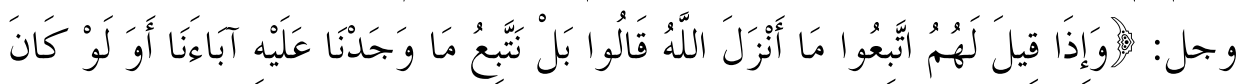

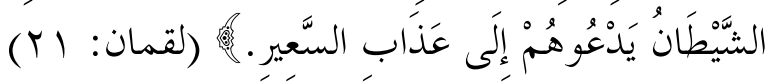

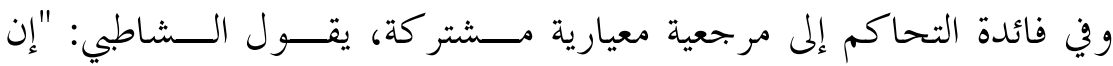

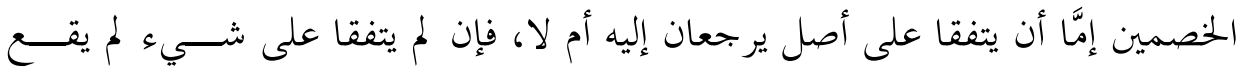

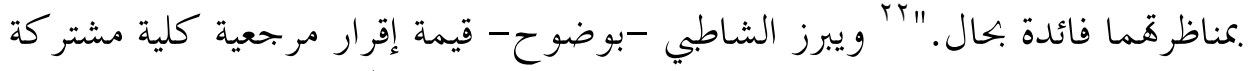

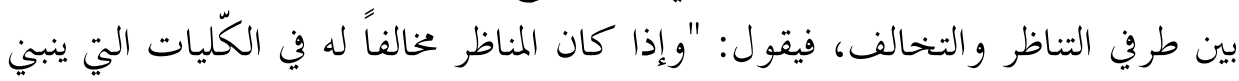

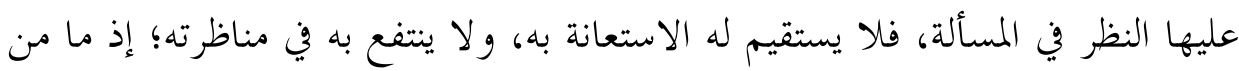

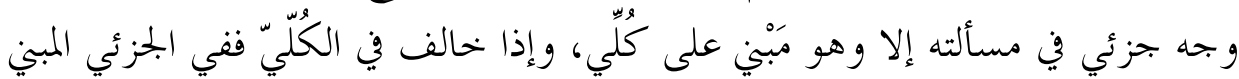

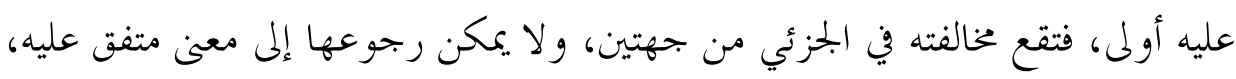

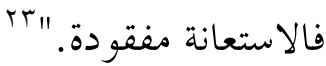

أما ضو ابط تأمين الحوار بين المتخالفين: فهي الضوابط التي يسعى الفكر الإسلامي

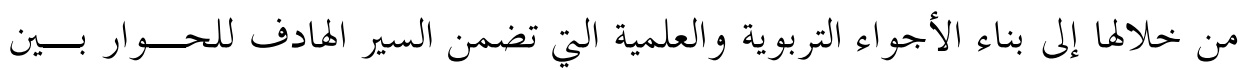
المتخالفين، نذكر منها:

التزام الأمانة العلمية في التباحث والتحاور؛ إذ يُعَدُّ التزام الأمانة في حياة الفرد

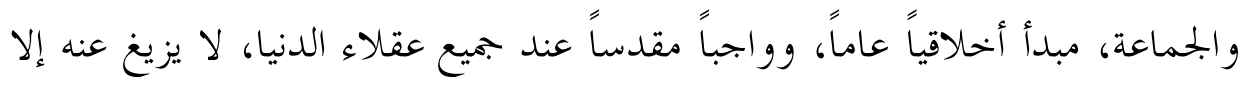

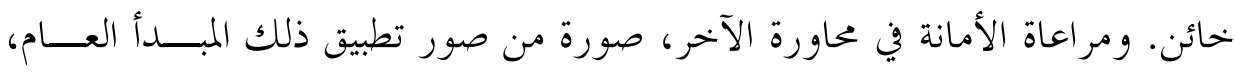

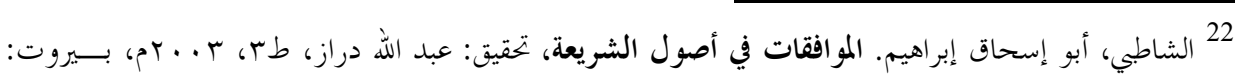

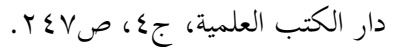

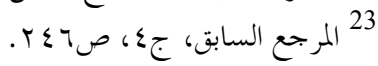


لذلك كان إخفاء الحقيقة العلمية أو الاحتيال عليها، گُجريمةَ خيانة لا تغتفر عند جميع

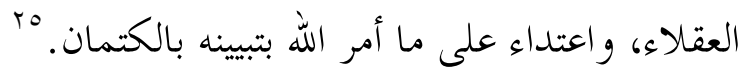

ومن هذا المنطلق، يتعين على أطر اف الخلاف أن يتمحض قصدهم في طلب الحق،

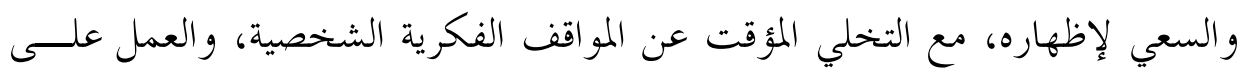

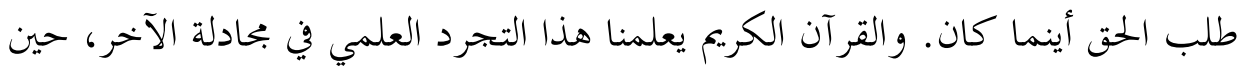

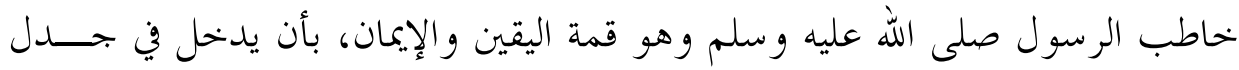

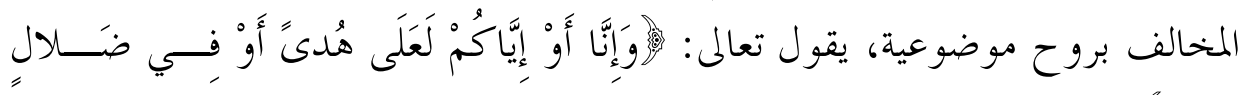

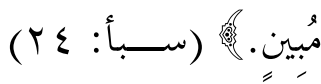

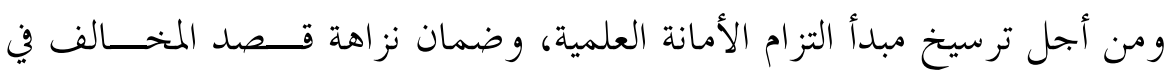

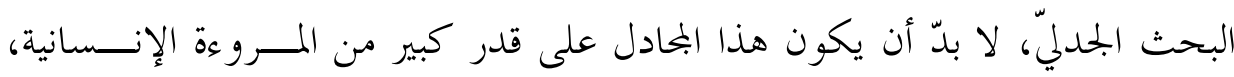

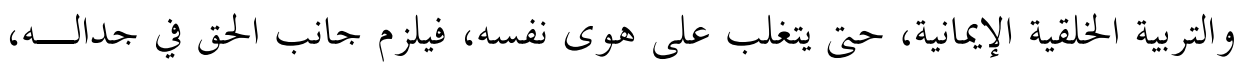

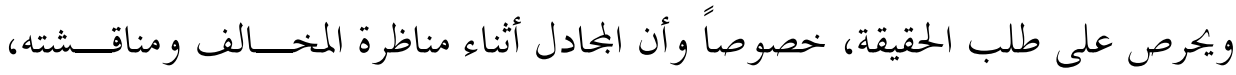

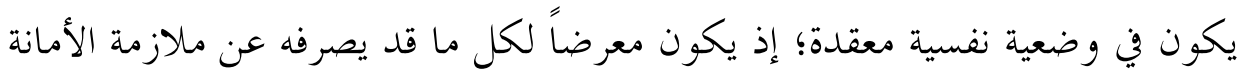

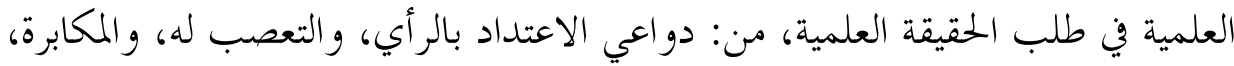

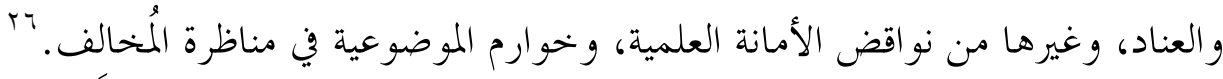
وهذا ما جعل أبا حامد الغزالي، يفضل أن تكون المناظرة بين أهل الاختستلاف في

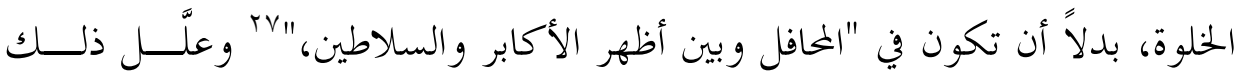

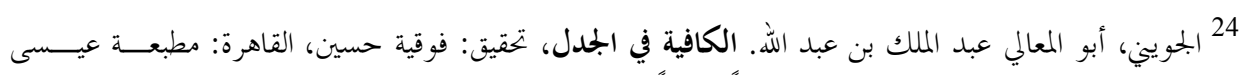

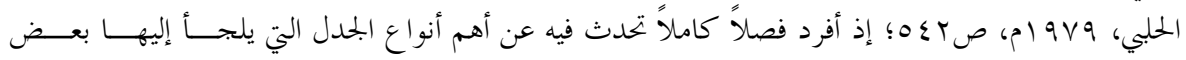
المتناظر ين، للتستر على ضعفهم وانقطاعهم. 25

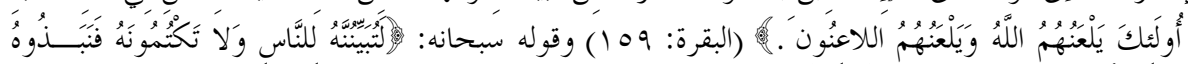

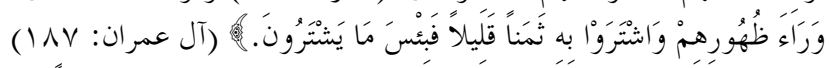

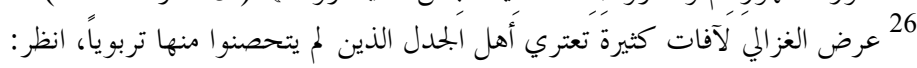

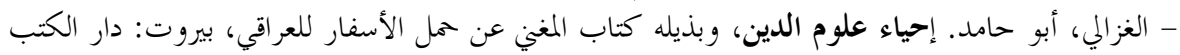

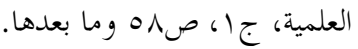

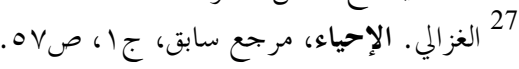




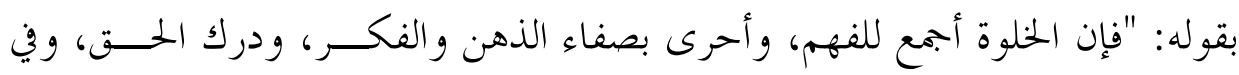

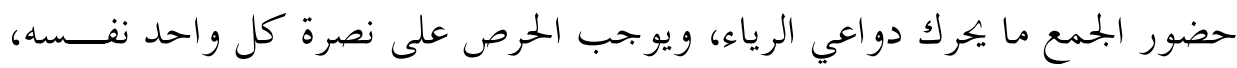

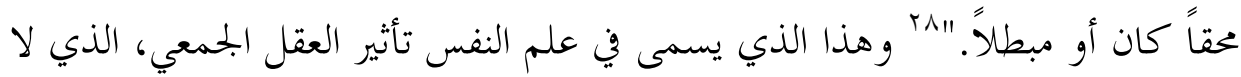
يساعد على ضبط النفس، ورزانة الرأي.

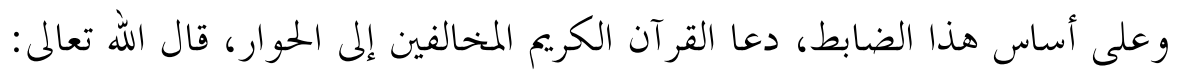

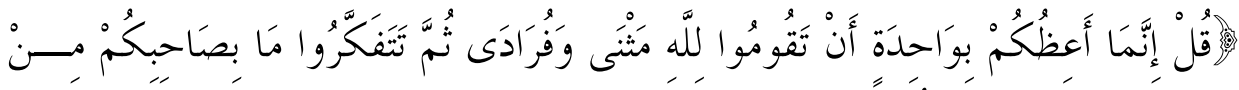

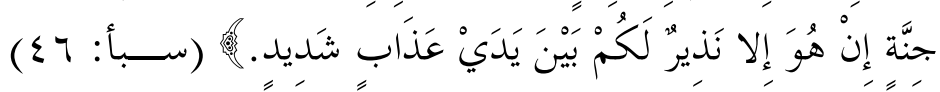

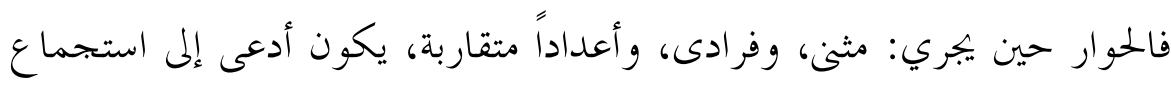

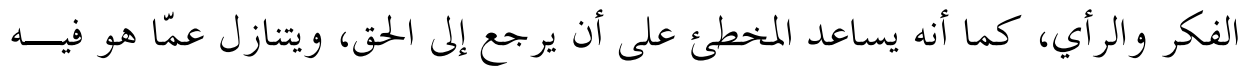

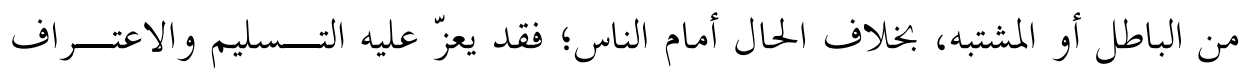

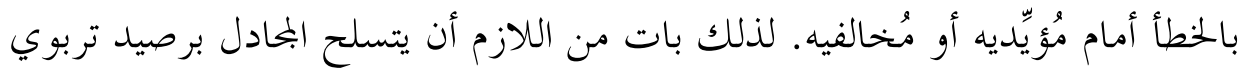

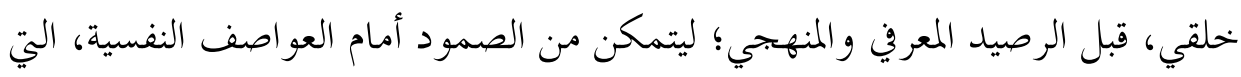
تحاول أن تعصف بأمانته العلمية، وإخلاصه في مقصده.

والتزام الأمانة العلمية في الجدل الحلافي، لم يكن موضع إشكال عند الصحابة -

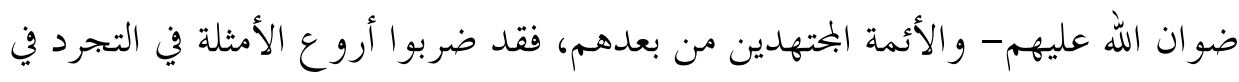

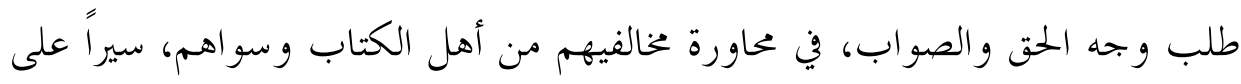

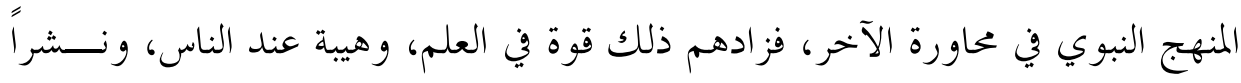
لدعوة الإسلام.

وقد كان شعار منهجهم، ما أعلنه أبو حنيفة -رحمه الله- حين قال: "هـــا رأي

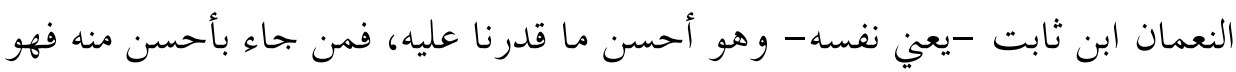


أولى بالصواب." "9qr وجاء الشافعي بعده ليقول: "ما ناظرت أحدا فأحببت أن يخطئ،

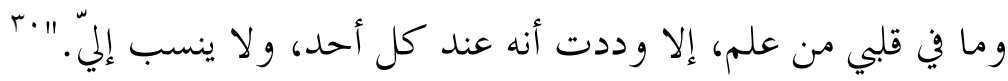
وتظهر صعوبة التقيد بالأمانة العلمية في الجدل، حينما نكون أمــام متجـــادلين

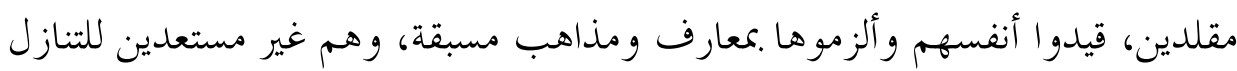

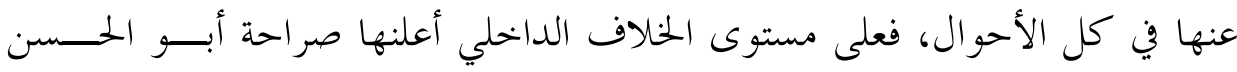

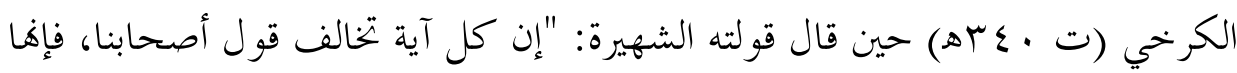

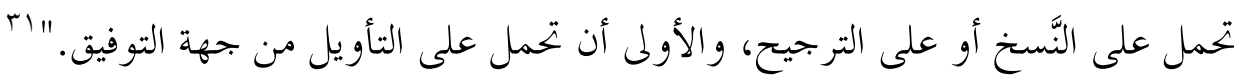

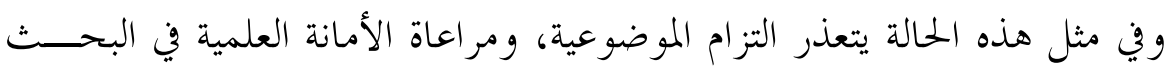

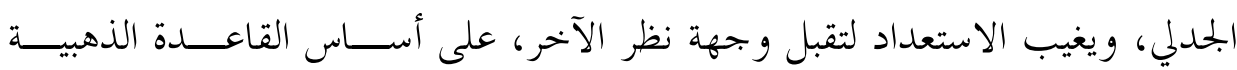

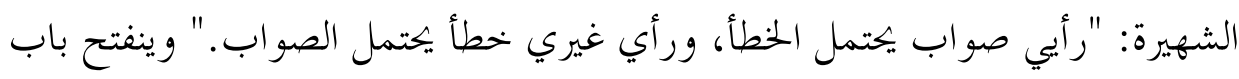

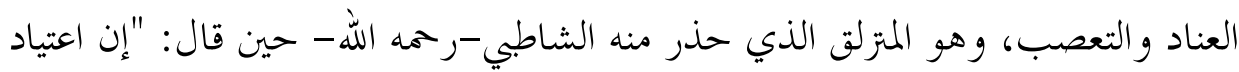

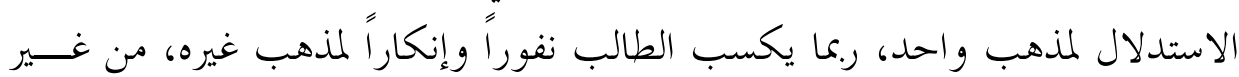

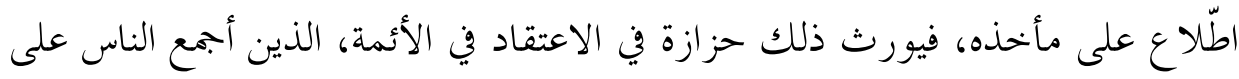

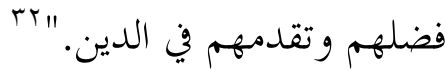

29

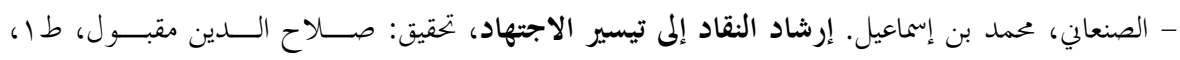

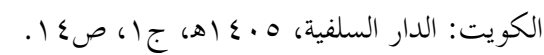

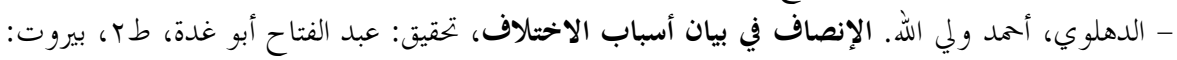

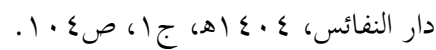

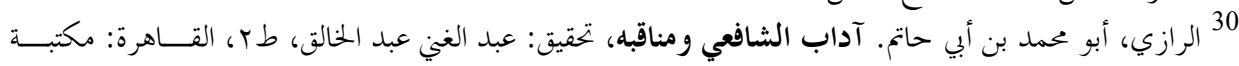

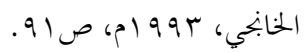

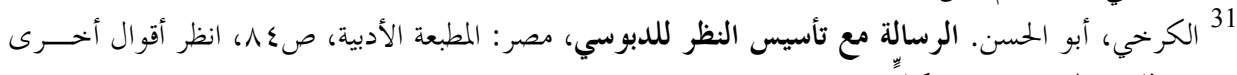

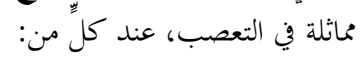

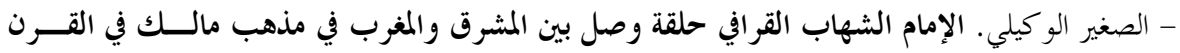

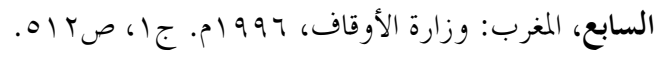

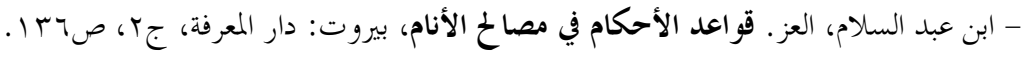

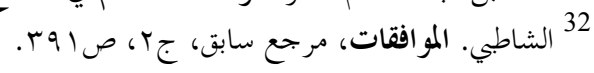




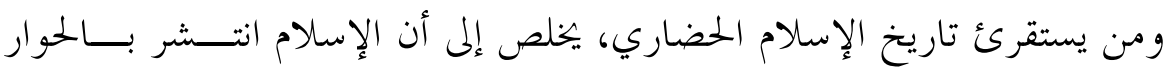

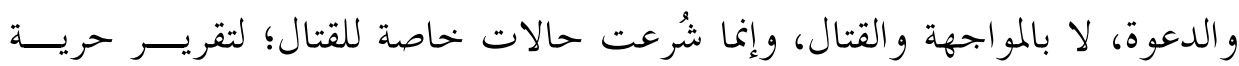

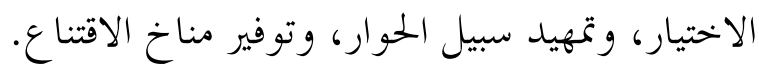

إنصاف المخالف واحترامه؛ إذ تتحدد العلاقة التي تربط بين المتجادلين -في بعدها

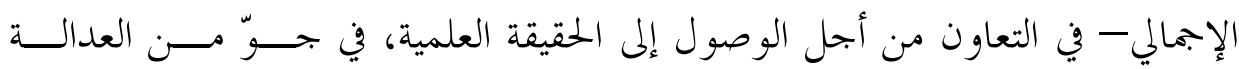

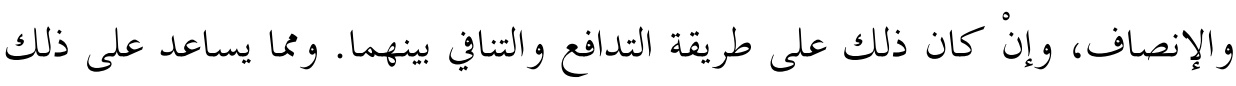

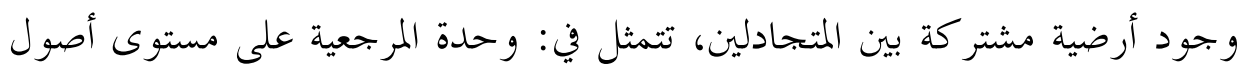

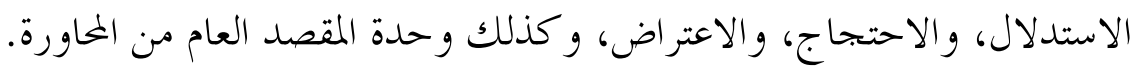
وعلاقة الإنصاف والاحترام علاقة متبادلة بين الطرفين المتجادلين، ويحرص عليها

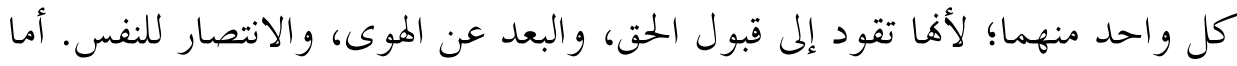

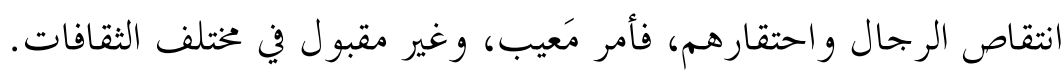
أما الإخلال بعلاقة الاحترام والإنصاف -ولو من جانب واحد- فإنه يفقد الحوار

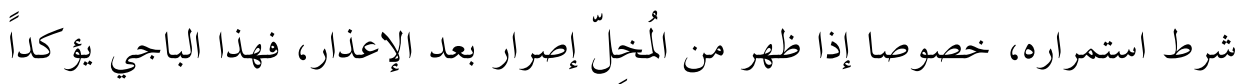

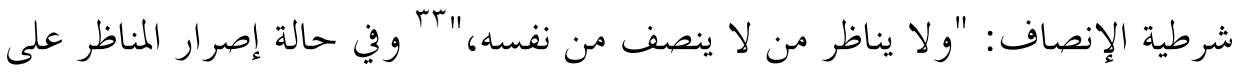

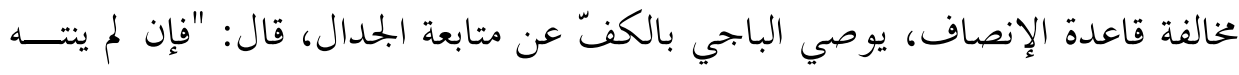

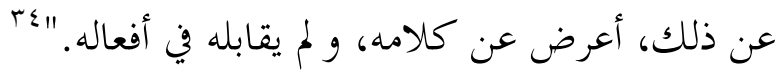

وتتجسد علاقة الإنصاف بين المتجادلين، في جملة من الإجـــــاءات الأخلاقيــة

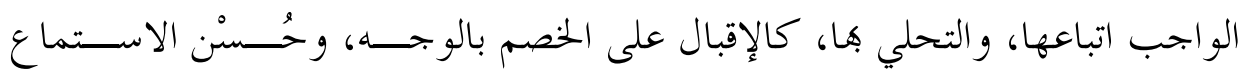

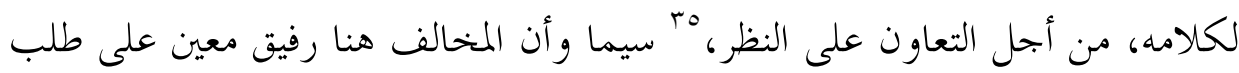

333 الباجي، أبو الوليد. المنهاج في ترتيب الحجاج، تحقيق: عبد الجيد تركي، ط؟، بيروت: دار الغرب الإسـلامي،

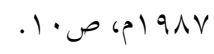

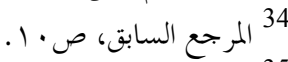

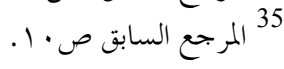




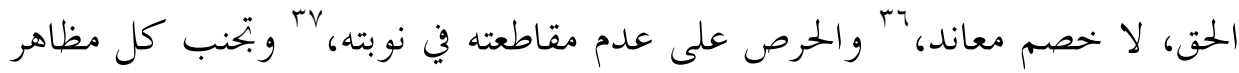

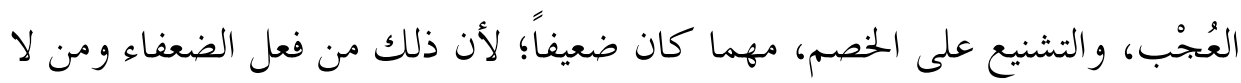
إنصاف عنده.

ورحم الله ابن البنّاء المراكشي الذي أكد مبدأ الإنصاف بقوله: "و كما تنظر بينك بنك

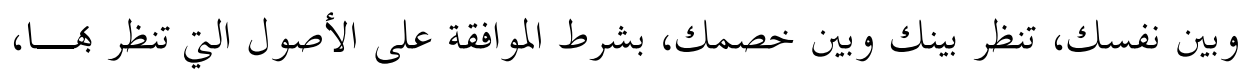

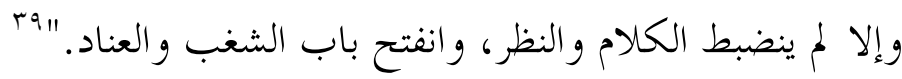

التزام حسن الاستدلال: بما أن الهدف الرئيس من محاورة المخالف هو الوصول

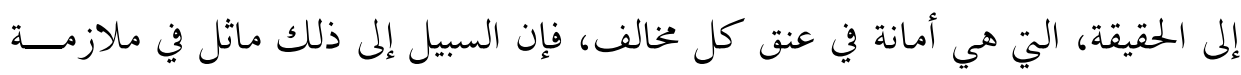
شروط الاستدلال الصحيح، ومنها: - الحرص على أن يكون الكلام بين المخالفين عن عِلْم وبيَّنَة، قال الباجي: "ولا لا

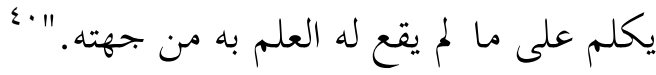

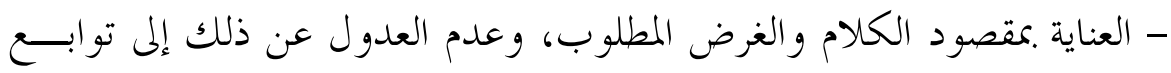

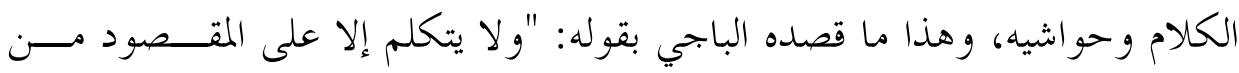

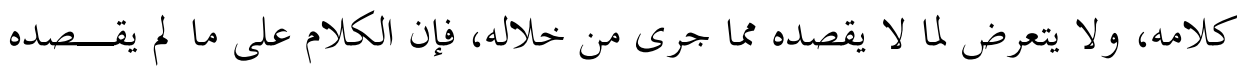

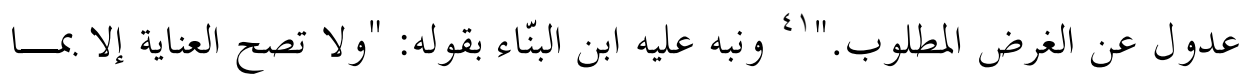

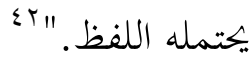

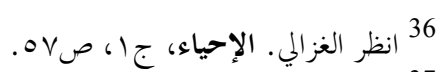

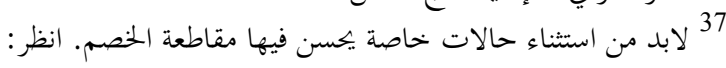

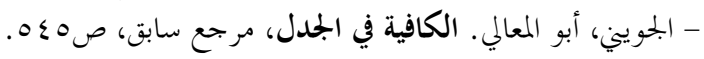

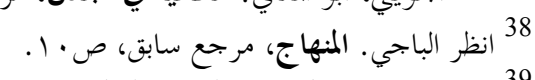

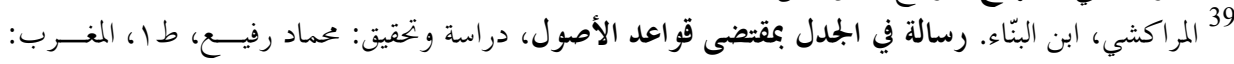

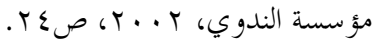

$$
\begin{aligned}
& \text { 40 } 40
\end{aligned}
$$

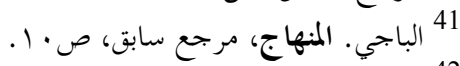

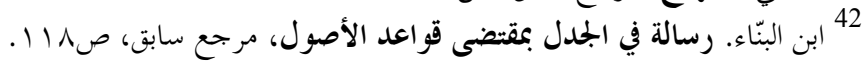




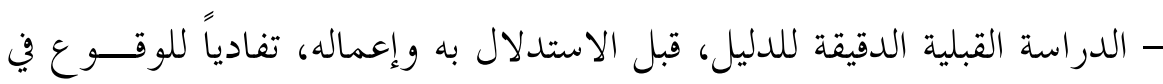

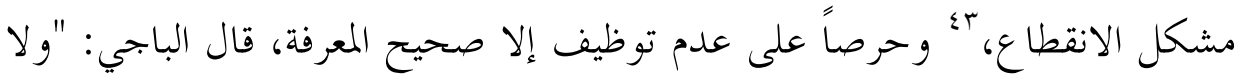

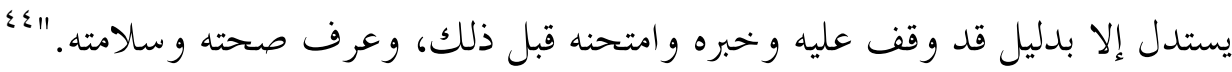
- الاجتهاد في اختصار الكلام، وتحاشي الإســهاب، "فــــإن الزلــل مقـــرون

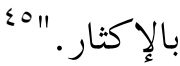

أولوية تحديد لغة الحوار: ذلك أن تحديد مدلول المصطلحات المراد استعمالها في

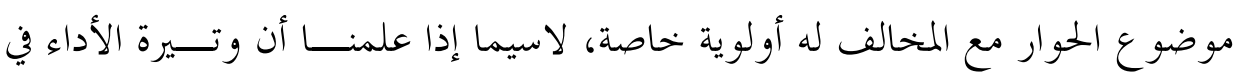

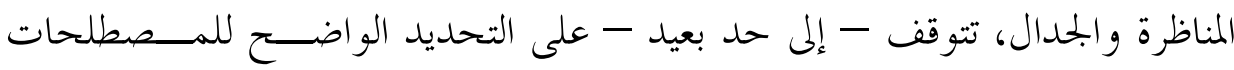

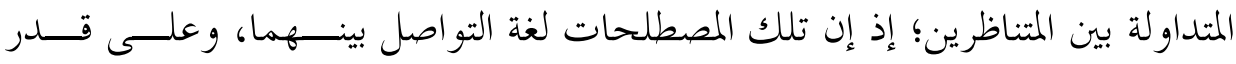

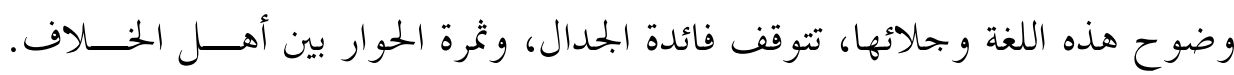

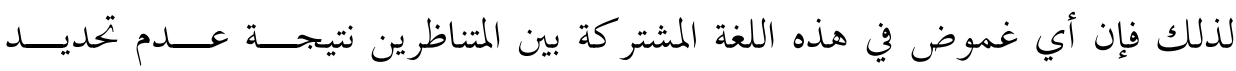

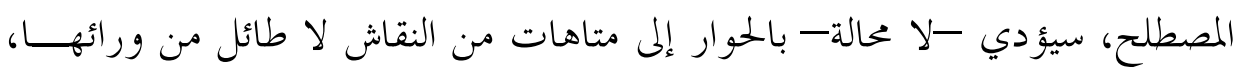

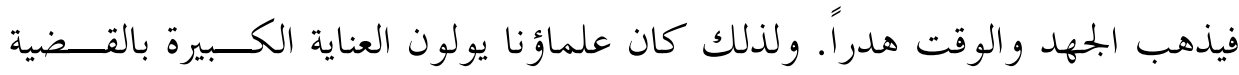

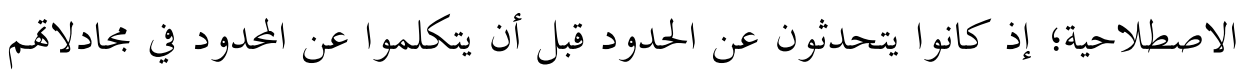

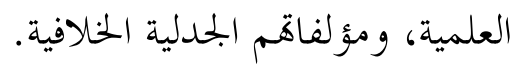

\section{ب الضو ابط النفصيلية}

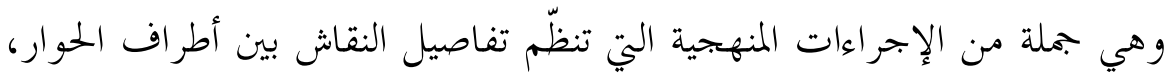

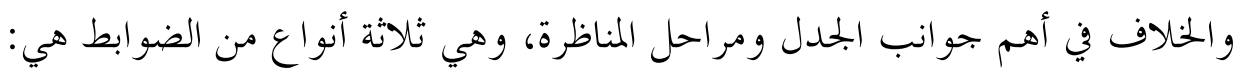

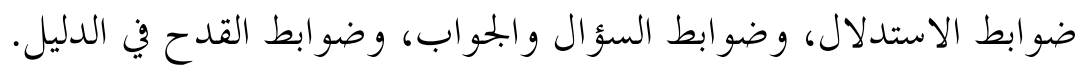

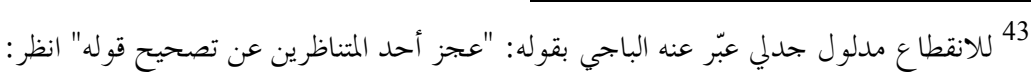

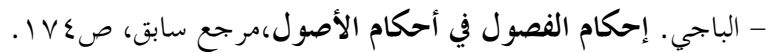

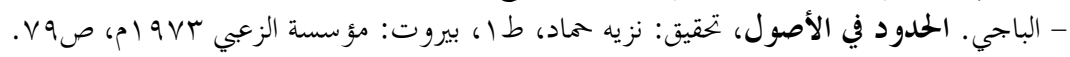

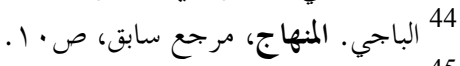

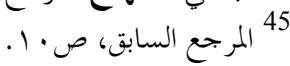


فضوابط الاستدلال، في مناظرة الآخر، وصيانته من التنــاقض والاضــطراب،

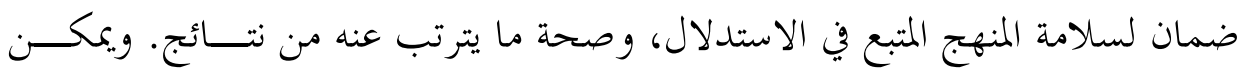

$$
\text { ضبط العملية الاستدلالية من خلال أمور أربعة: }
$$

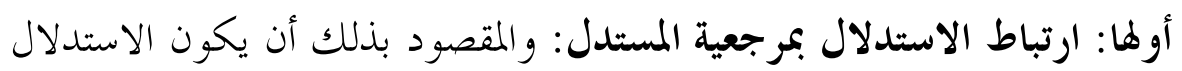

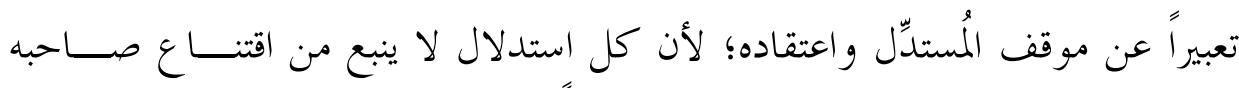

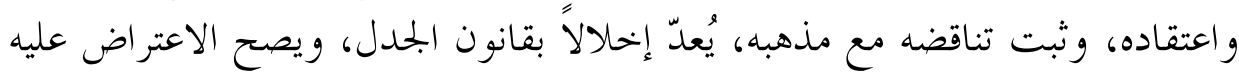

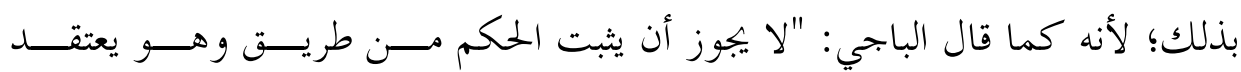

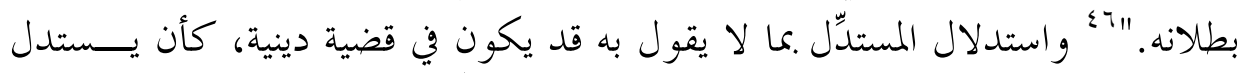

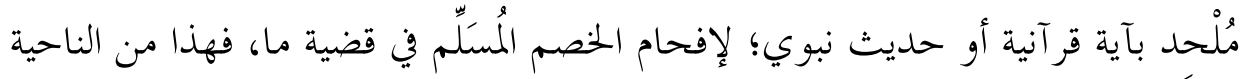

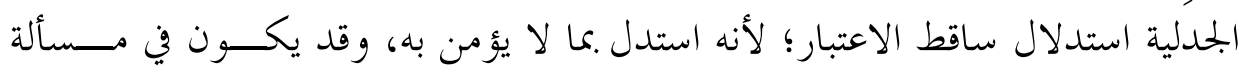

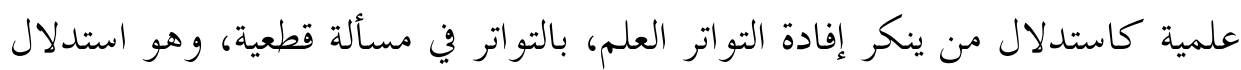
مكا لا يقول به، وهو مردود.

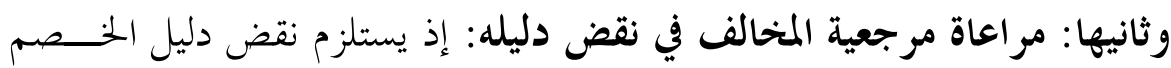

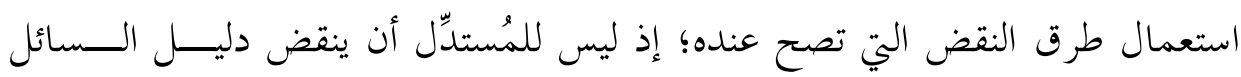

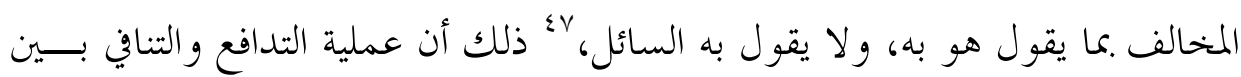

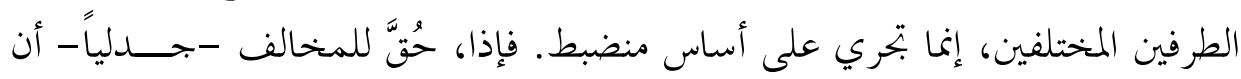

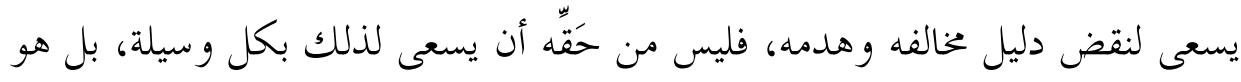

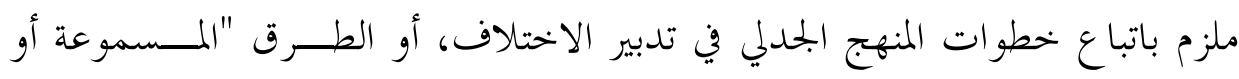

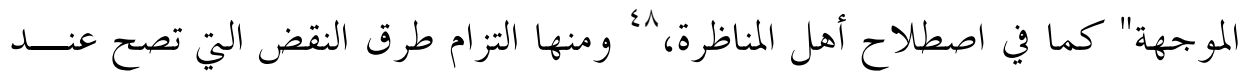

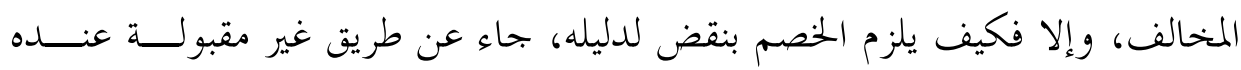

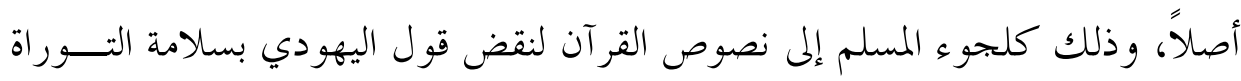

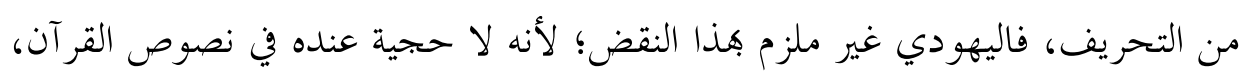

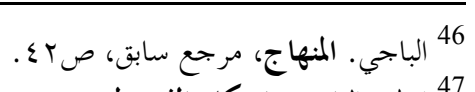

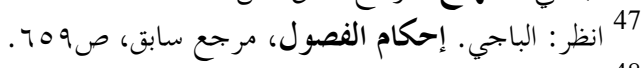

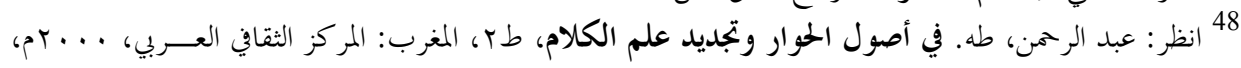




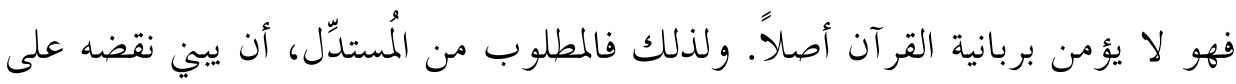

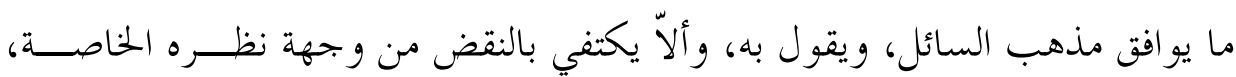

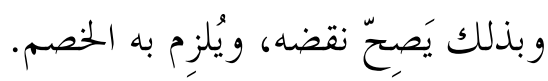

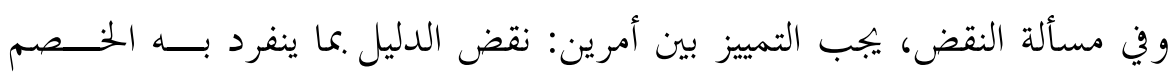

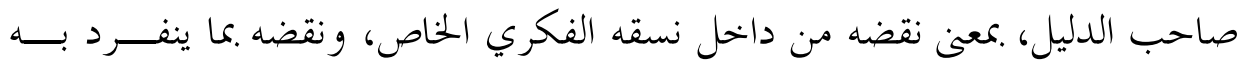
الناقض، 9؛ أي ضمن نسقه الفكري الخاص به أيضا، كما في المثال السابق.

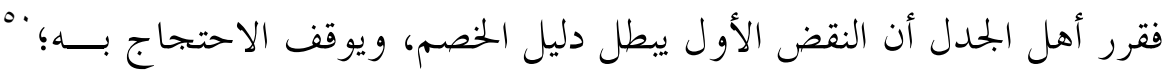

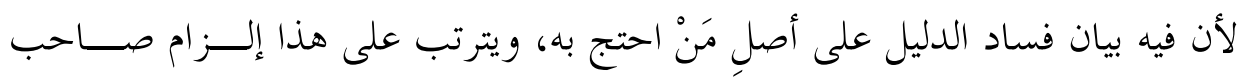

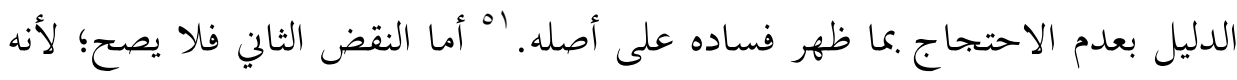
اعتراض بوجهة نظر خاصة لا تلزم سوى صاحبها.

وثالثها: منع قَلْب القَلْب: فإذا كان مصطلح القلب عند أهل الجحدل يتحدد معناه

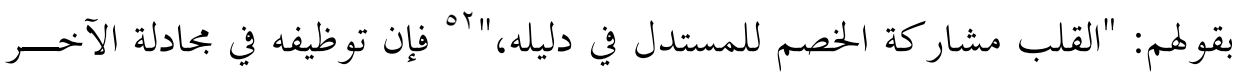

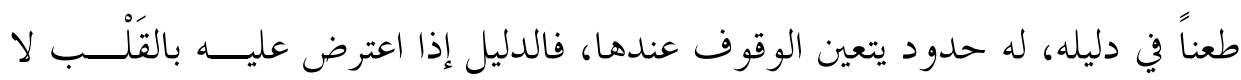

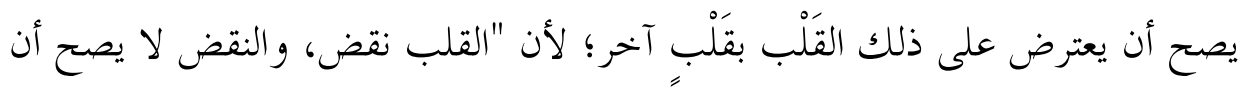

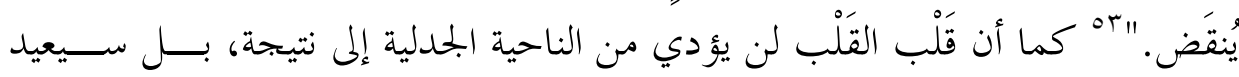

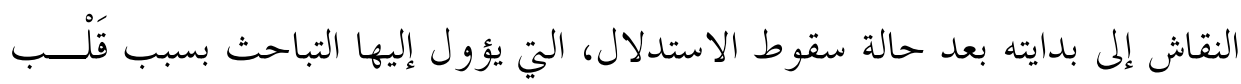

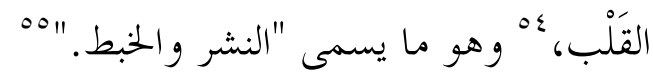

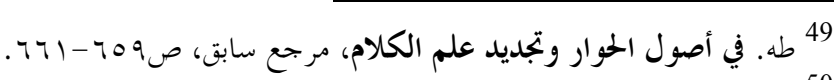

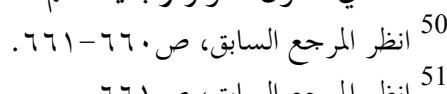

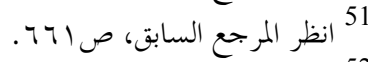

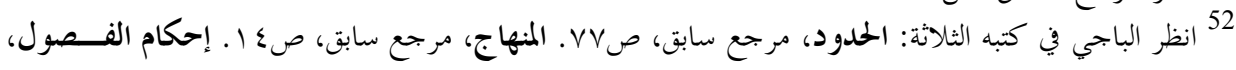

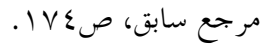

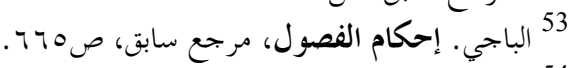

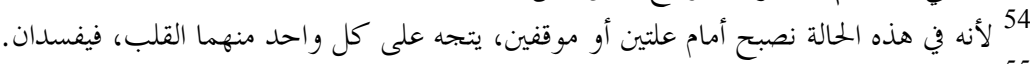

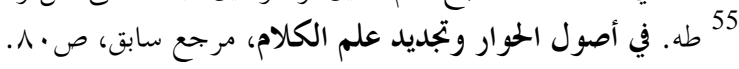


ورابعها: منع الخروج عن الموضوع: فمن أوجه ضبط العملية الاسـتـلالية في

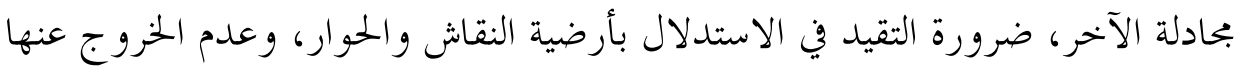

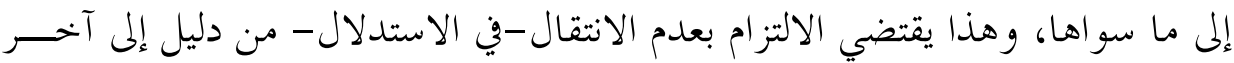

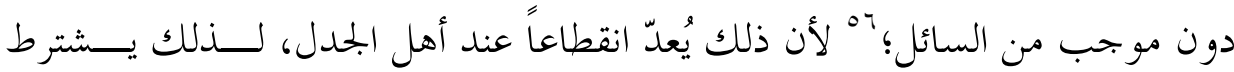

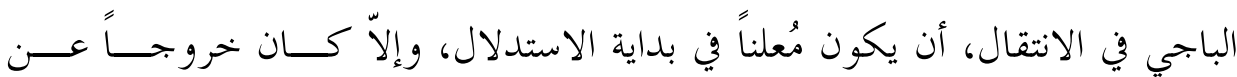

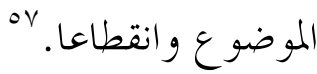

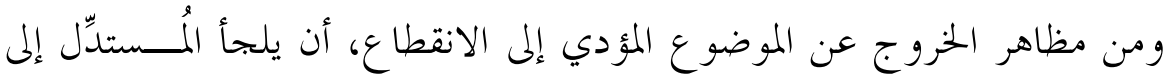

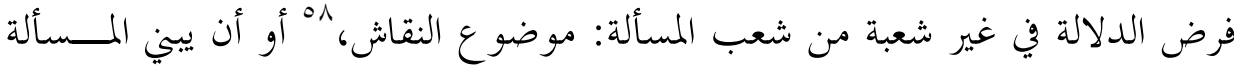

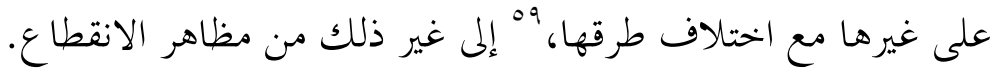
ومن خحلال القضايا السابقة تتبين أهمية ضبط العملية الاستدلالية، وتقنينها أثنـــاء

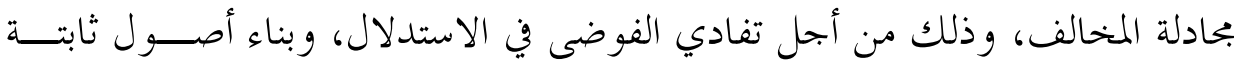
موحدة للاحتكام إليها.

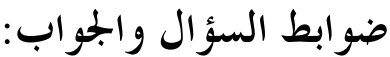

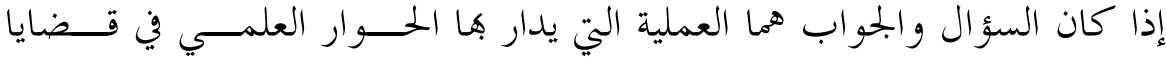

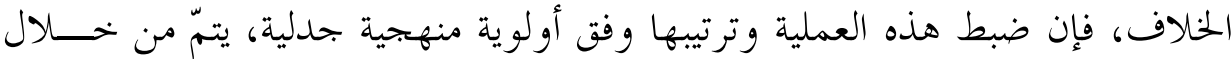

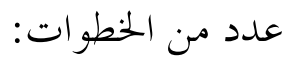

الحططوة الأولى: معرفة مذهب المخالف: فأول ما ينبغي البدء بــهـه في الحــــوار،

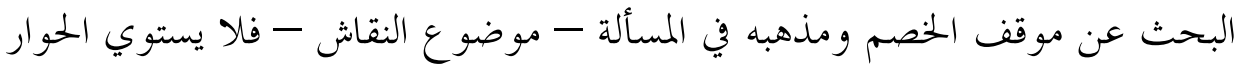

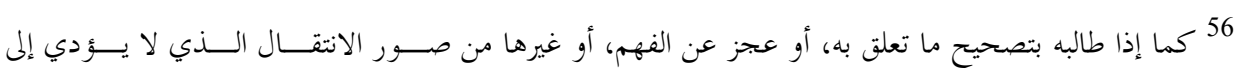

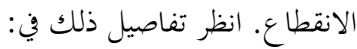

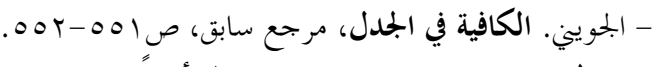

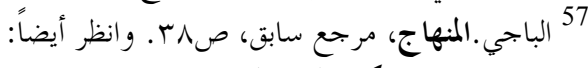

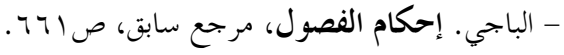

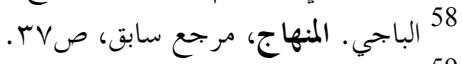

$$
\begin{aligned}
& 59 \text { المرجع السابق، صمراج. }
\end{aligned}
$$




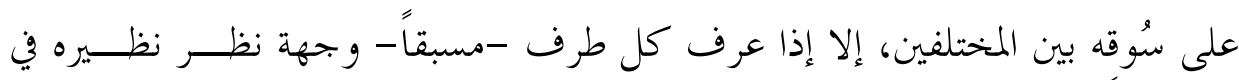

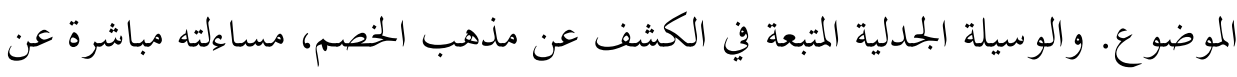

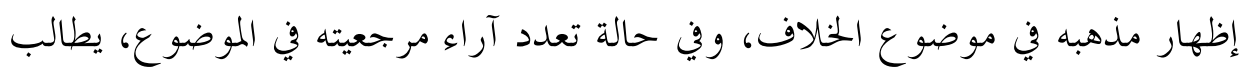

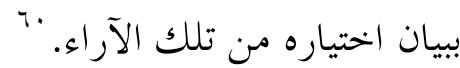

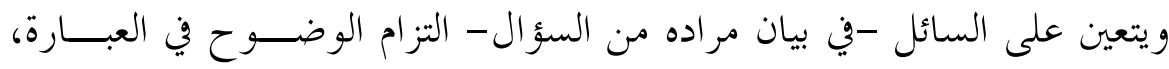

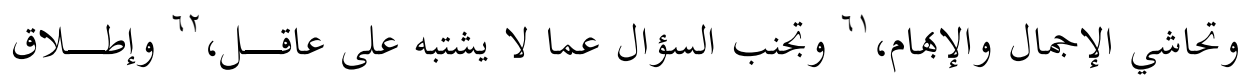

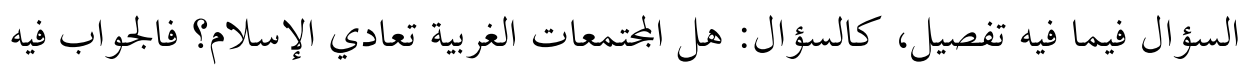

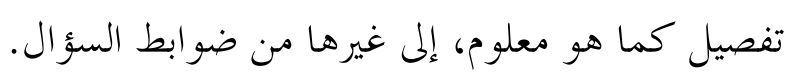

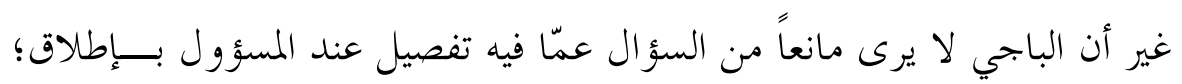

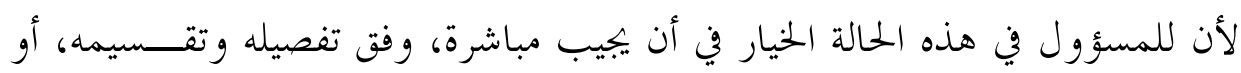

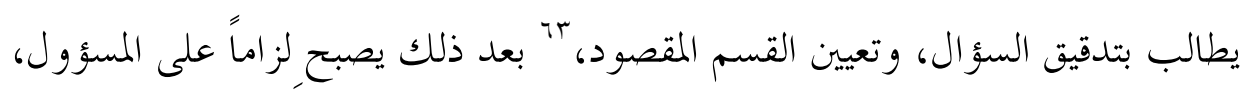

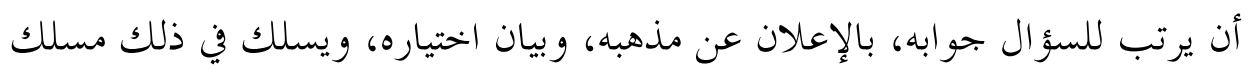
الوضوح.

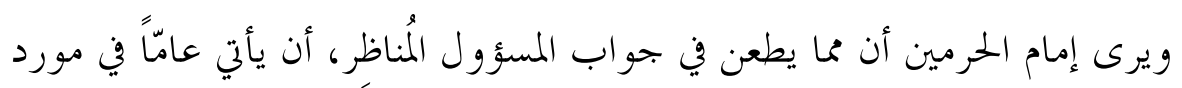

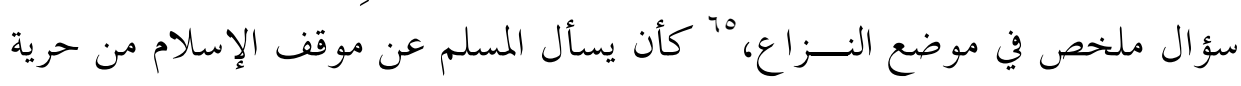
المعتقد، فيجيب بييان سماحة الإسلام وسمو مبادئ فئه.

الخطوة الثانية: هي البحث عن دليل الخصم: فالبحث عن الدليل الذي اســتند

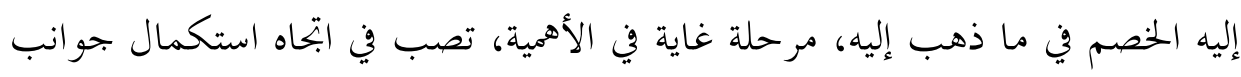

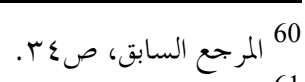

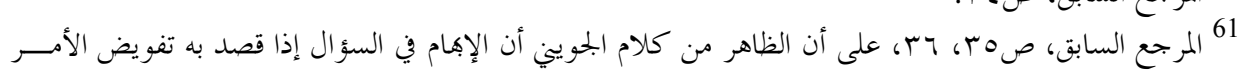

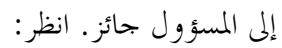
- الجوين. الكافية في الجدل، مرجع سابق، ص. م. م.

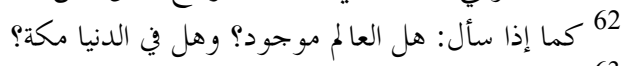

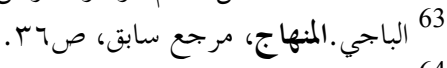

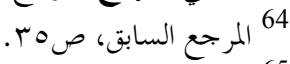

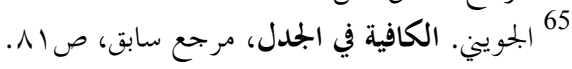


أرضية النقاش؛ فبالدليل يتميز القول الساقط من القول المعتبر. وقد علّمنا القرآن الكريم

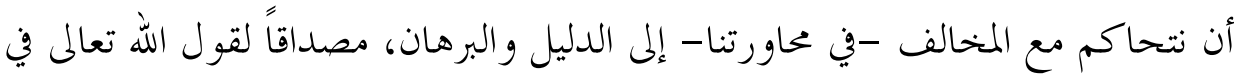

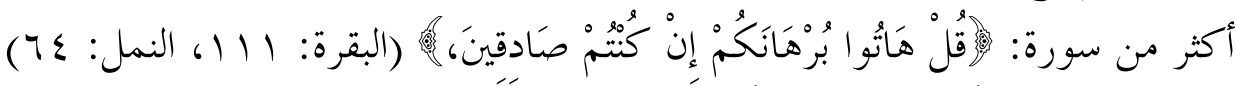

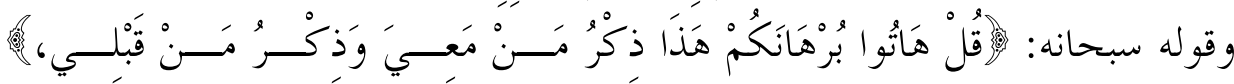

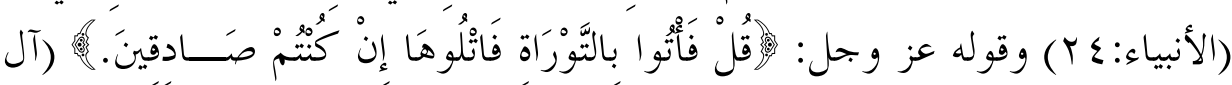

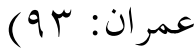

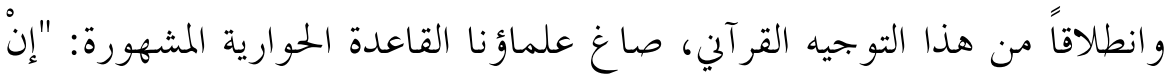

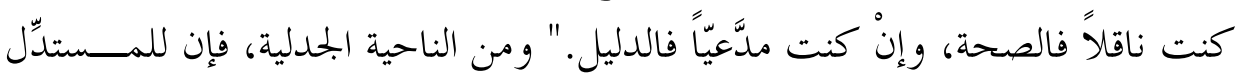

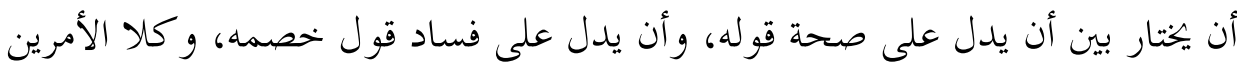
جائز.

والحطوة الثالثة: هي البحث عن وجه الدلالة: ليكتمل بذلك بناء شروط البحث

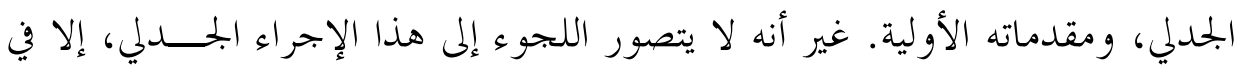

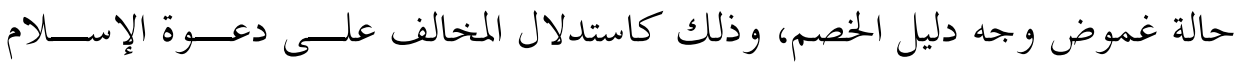

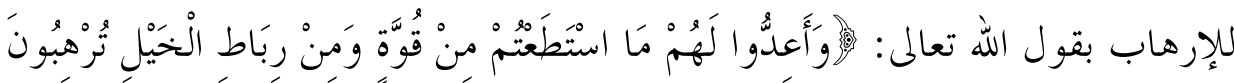

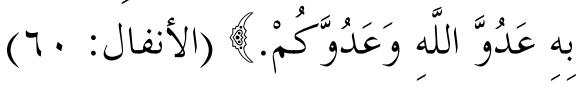

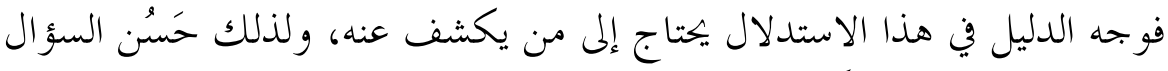

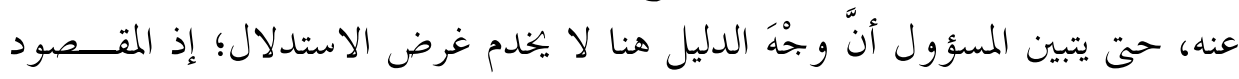

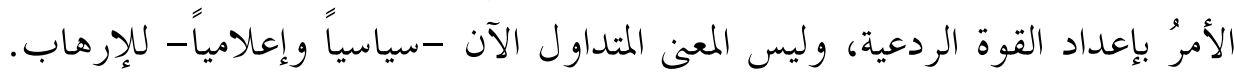

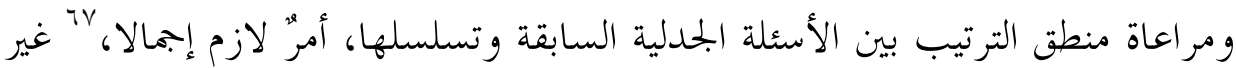

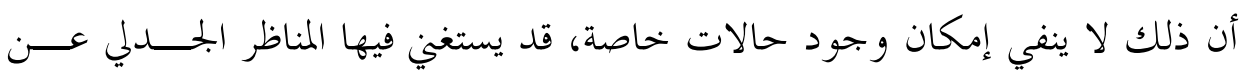

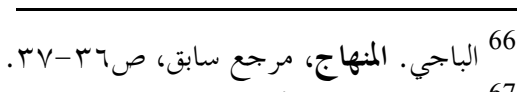

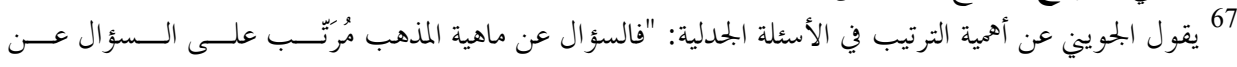

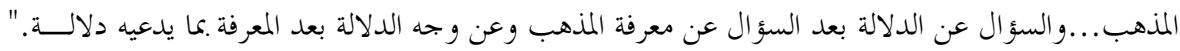


خطوة من تلك الخطو ات بحسب الموجب؛ لأن كل خطوة إنما يتم اللجوء إليها، عندما

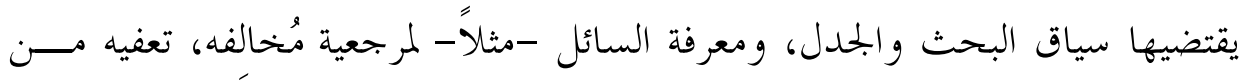
خطو ات البحث عن إثباته، كما أن وضوح و وجه الدلالة في دليل الخصم يغني السائل عن السؤال عنه، و وهذا.

وذهب الجويني في تأكيد هذا المعنى، إلى أن جمهور أهل النظر، على أن "الــسائل

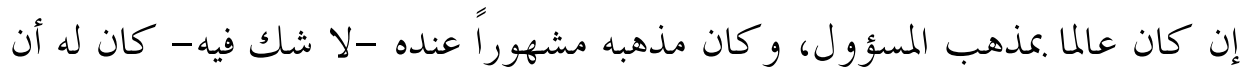

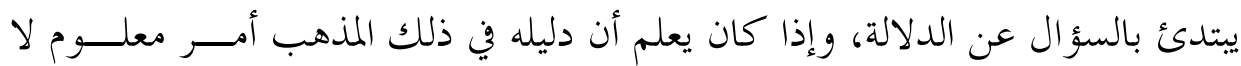

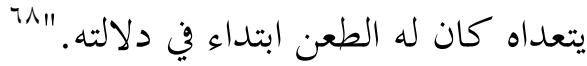

\section{ضو ابط القدح في الدليل:}

تمثل ضوابط القدح في الدليل، المرحلة الفكرية التي يتفاعل فيها النقاش الجــــلي،

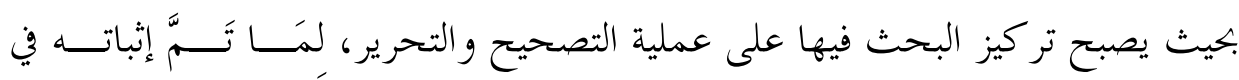
المرحلة التمهيدية السابقة (ضوابط السؤال والجواب)، مع اختبار الحتبار مدى إمكانية قيــام

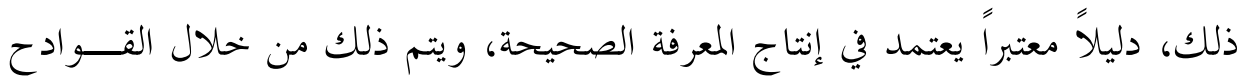
التالية:

القادح الأول هو المطالبة؛ إذ تشكل المطالبة الحلقة الأولى في سلـسلة وجــــوه القدح في الدليل، وذلك ضمن السياق العام لعملية التــصحيح والاختبــــار لــــليل

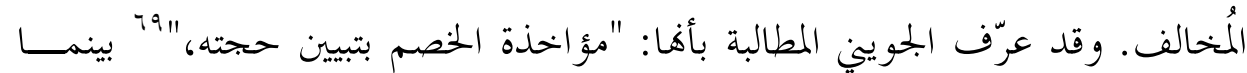

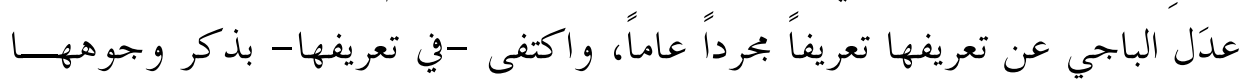

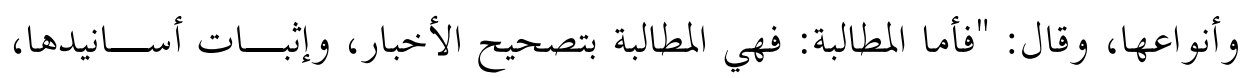
و المطالبة بتصحيح الإجمال وإثباته، والمطالبة بإيجاد العلة وتصحيحها، وغير ذلك مـــن

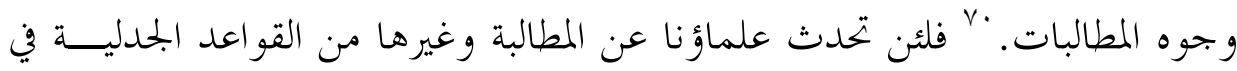

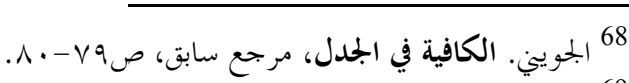

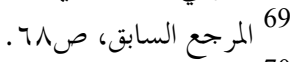

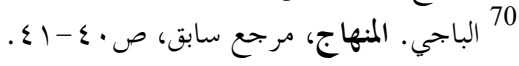


سياق أصولي، فمن باب ارتباط المنهج بالموضوع، وإلا فهذه القواعد الجلدلية تمثل منهج تدبير الخلاف بصفة عامة، سواء كان خلافاً داخلياً أو خارجياً.

أما الوظيفة الجدلية لقادح المطالبة، فتتمثل في ناحيتين: الناحية السلبية: وفيها يمنع

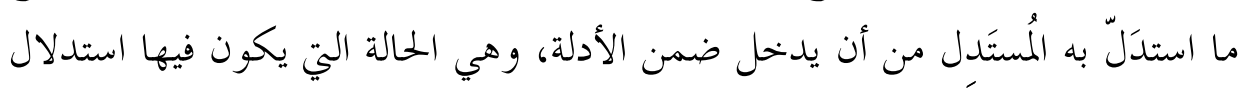

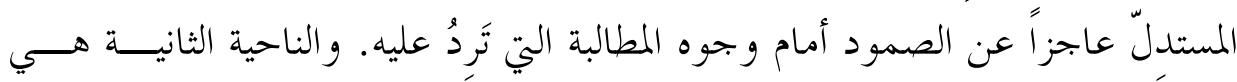

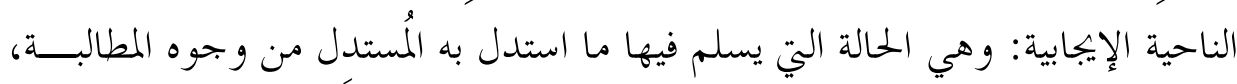

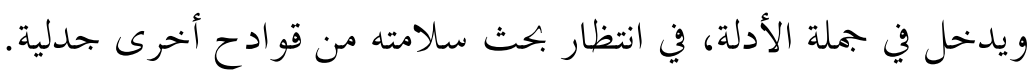

والقادح الثاني هو الاعتراض، وللاعتراض معنيان: أحدهما عام، والآخر خاص.

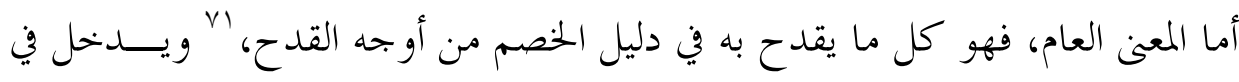

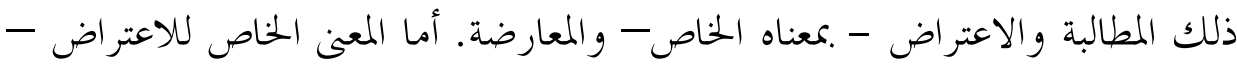

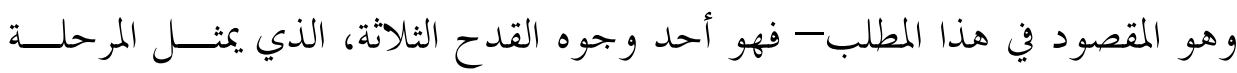

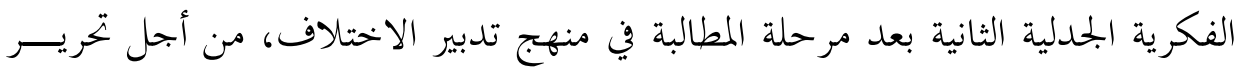
الدليل، وبناء المعرفة الصحيحة.

ويتأكد هذا المعنى الخاص للاعتراض، من خلال تقسيم الباجي وجوه القـــدح في

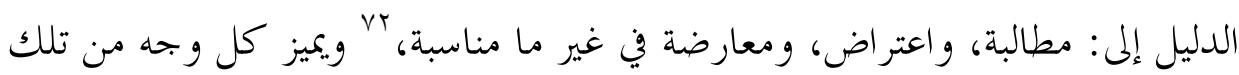

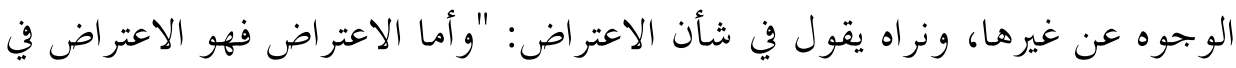
نفس الدليل .بما يبطله."

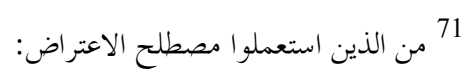

- الشيرازي (أبو إسحاق) في كتاب المعونة في الجلدل، تحتيق عبد الجيد تركي، بيروت: دار الغرب الإسلامي، (م) 911

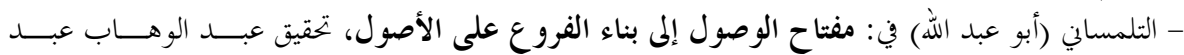

$$
\begin{aligned}
& \text { اللطيف، بيروت: دار الكتب العلمية، صلاح آلا، وما بعدها. } \\
& \text { - الباجي. المنهاج، مرجع سابق. } \\
& 72
\end{aligned}
$$

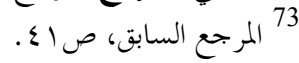




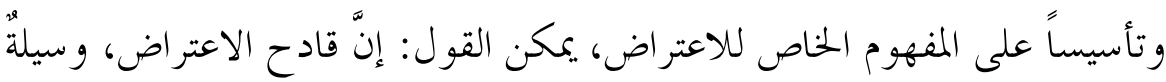

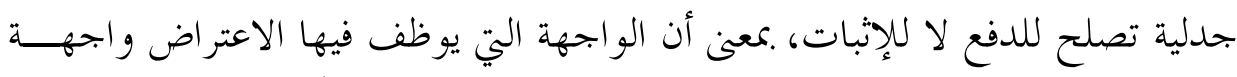

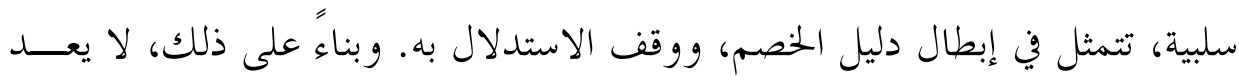

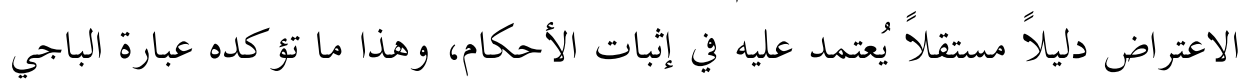

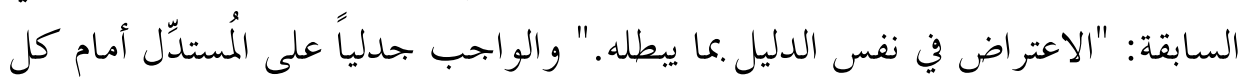

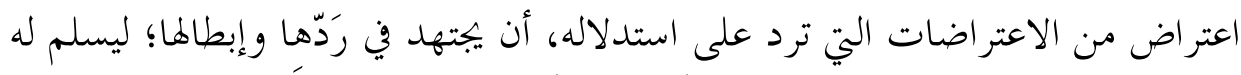

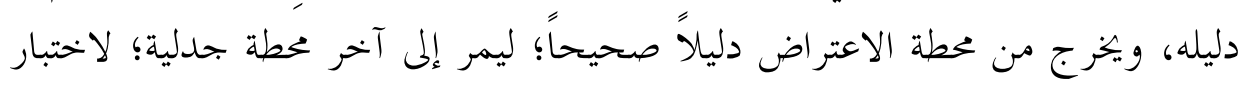
مدى سلامته من قادح آخر.

والقادح الثالث هو المعارضة: ويُعد هذا القادح آخر محطة فكرية جدليسـة مـــن

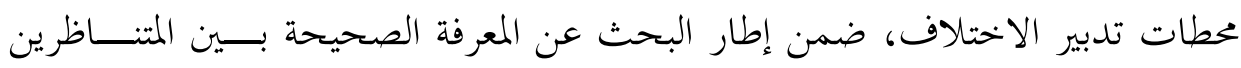

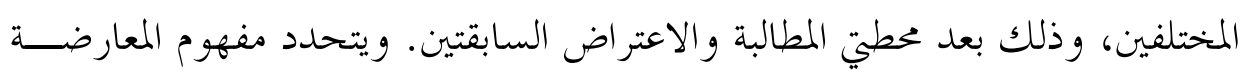

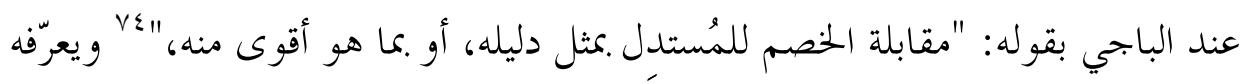

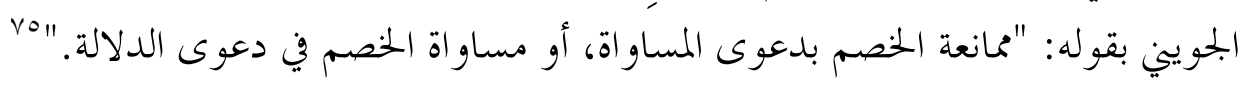

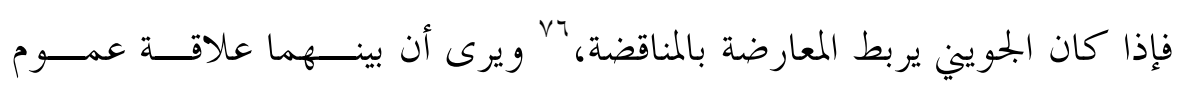

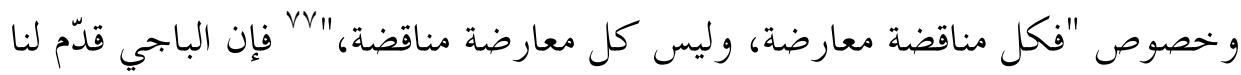

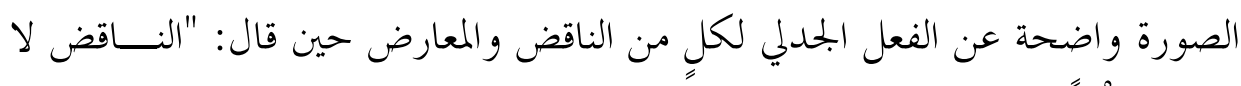

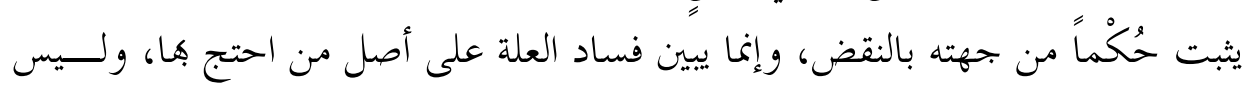

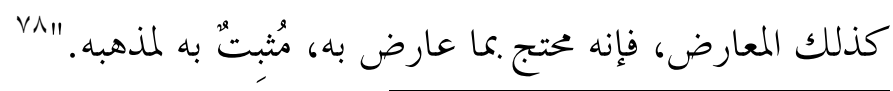

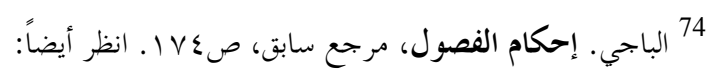

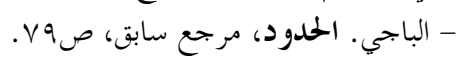

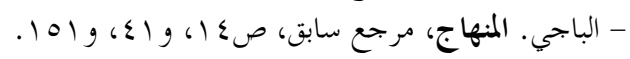

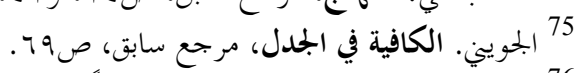

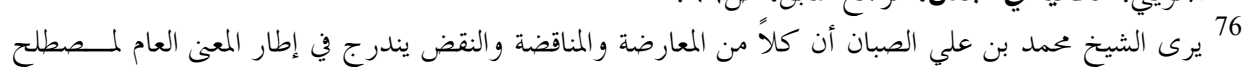

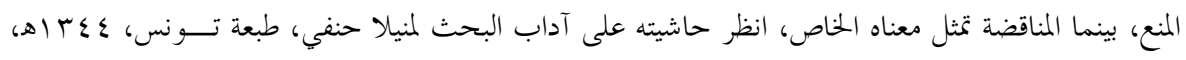


وبناء" على ذلك، فإننا نصبح أمام عمليتين فكريتين: إحداهما سلبية ترتبط بـــليل

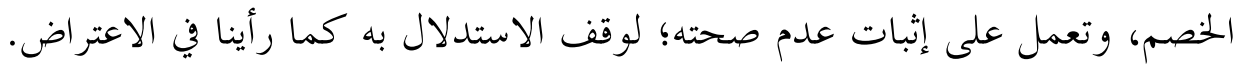

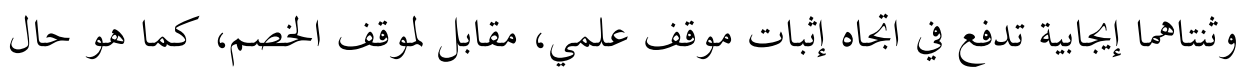

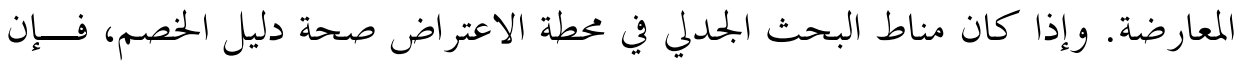

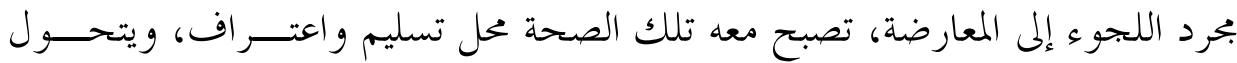
النقاش إلى موضوع البحث عن الدليل الأول بالاعتماد على إنتاج المعرفة.

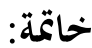

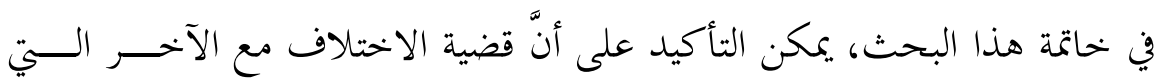
كانت مدار هذا البحث، تم تدبيرها في المرجعية الإسلامية بإحكام وفق أصول رصينة،

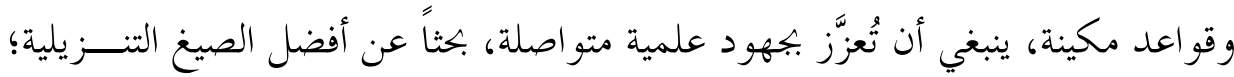
لإدارة الاختلاف مع الآخر الملائمة لأحو ال الزمان وأهله.

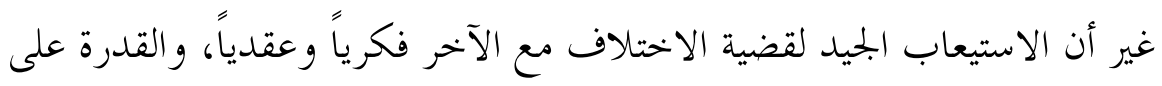

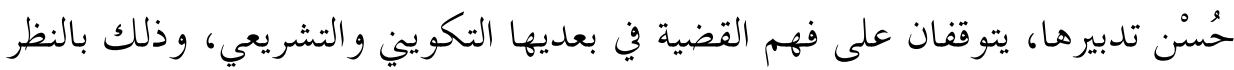

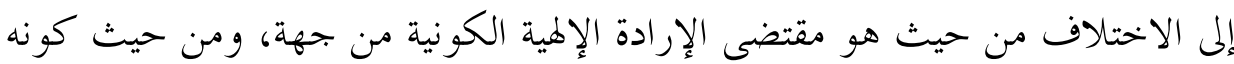

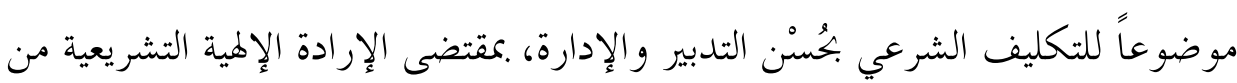

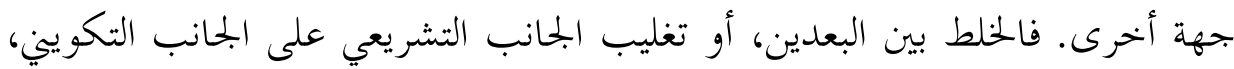

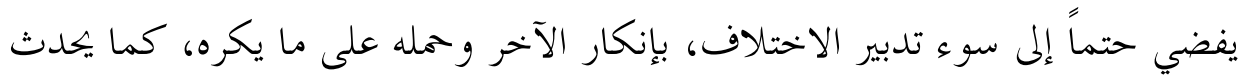

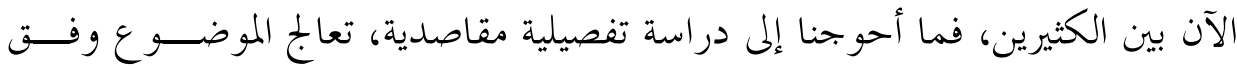
ثنائية القصد الكوني و القصد الشرعي. واتضح من خلال هذه الدراسة، أن القرآن الكريم قدّم لنا منهجاً متكاملاً حيوياً

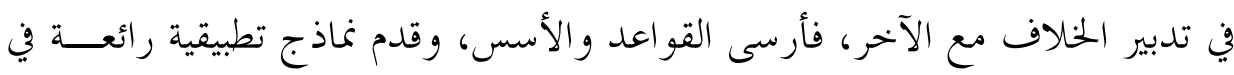

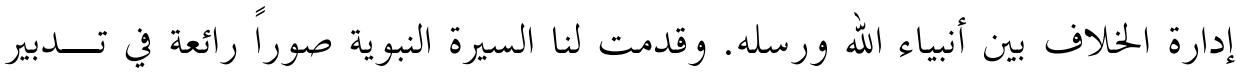




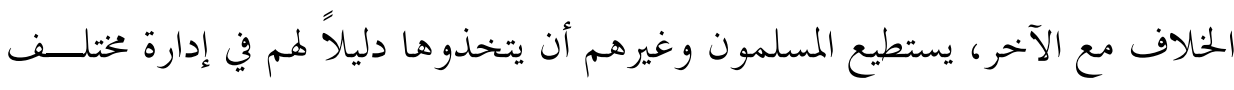

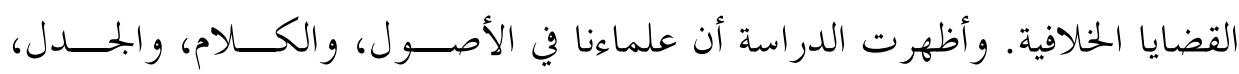

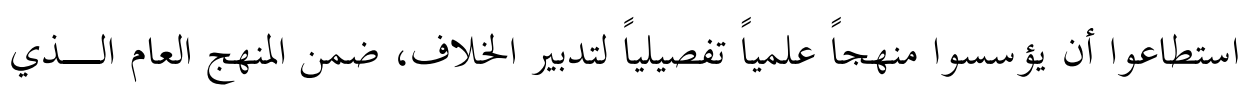

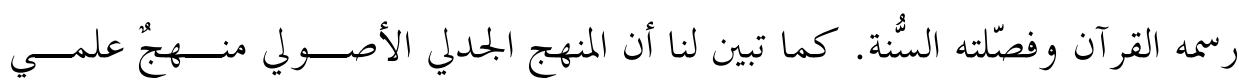

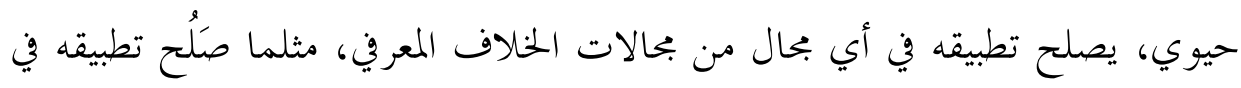

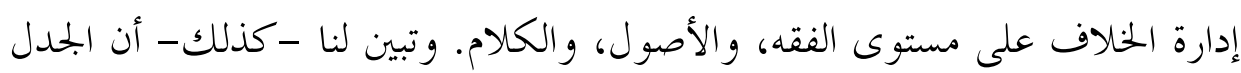

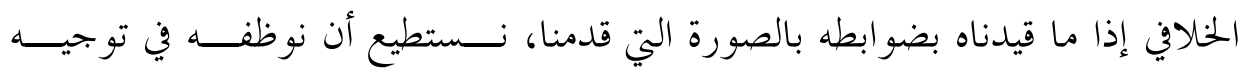

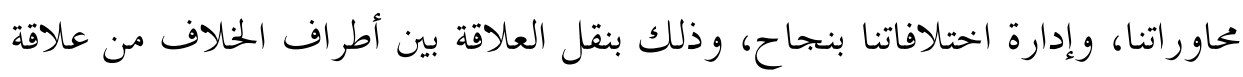

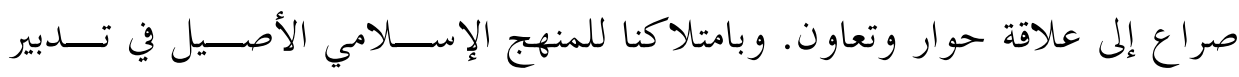

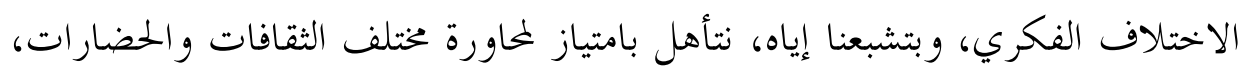
وقيادة أهلها للتعاون في بناء المشترك الإنساني، وتمحيص المتعرفة الإنسانية. 